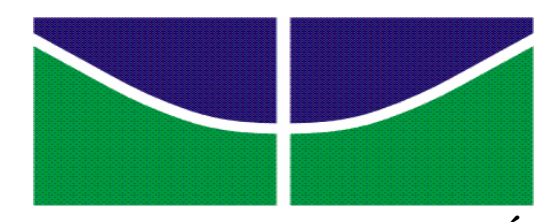

\author{
UNIVERSIDADE DE BRASÍLIA \\ INSTITUTO DE CIÊNCIAS HUMANAS \\ DEPARTAMENTO DE SERVIÇO SOCIAL
}

DENISE SILVA COSTA

\title{
EDUCAR OU PUNIR: DILEMAS NA PRÁTICA SOCIOEDUCATIVA COM ADOLESCENTES EM REGIME DE SEMILIBERDADE NO GAMA LESTE - DF
}


DENISE SILVA COSTA

\title{
EDUCAR OU PUNIR: DILEMAS NA PRÁTICA SOCIOEDUCATIVA COM ADOLESCENTES EM REGIME DE SEMILIBERDADE NO GAMA LESTE - DF
}

\author{
Monografia apresentada ao \\ departamento de Serviço Social na \\ Universidade de Brasília para a obtenção \\ do diploma de Graduação \\ em Serviço Social, sob a orientação da \\ Professora Maria de Fátima Castilhos \\ Schaeffer.
}

Brasília, julho de 2008 
Universidade de Brasília - UNB

Instituto de Ciências Humanas - IH

Departamento de Serviço Social

Trabalho de Conclusão de Curso - TCC

\title{
EDUCAR OU PUNIR: DILEMAS NA PRÁTICA SOCIOEDUCATIVA COM ADOLESCENTES EM REGIME DE SEMILIBERDADE NO GAMA LESTE - DF
}

\author{
Aluna: Denise Silva Costa \\ Orientadora: Maria de Fátima Castilhos Schaeffer
}

Banca Examinadora:

Assistente Social Elionilde Marques da Silva - SEJUS

Prof. Dr. Mario Ângelo Silva - UNB

Brasília

Julho de 2008 
Dedico ao meu pai José dos Santos, que me ensinou com sua vida o valor da educação, por ter sido muito mais que um pai; foi aquele que tornou meu sonho possível. 


\section{AGRADECIMENTOS}

A Deus por me ensinar a ser forte mesmo nas adversidades, por tua força e amizade por ser um pai sempre leal.

Aos meus pais Maria da Conceição e José dos Santos, por todo o trabalho, doação, dedicação e carinho elementos sem os quais não seria possível realiza esse sonho.

Ao meu irmão Denilson Silva, por toda a paciência e apoio, por estar presente em todos os momentos da minha vida e pelo seu companheirismo eterno. Ao meu irmão Denys Silva, porque do jeito dele, sempre acreditou e torceu por mim.

As minhas queridas amigas Marcela Duailibe, Rozânia Piris e Tatiana Travassos, por todo carinho e apoio e por fazer da minha vida acadêmica uma história de aventura, desafios e comédia. Por terem se tornado muito mais do que amigas de curso, mas amiga para a vida toda.

À minha eterna amiga Fabiana Firmino, por todas as suas orações e palavras amigas, por ter sido para mim um exemplo de determinação.

A Meirelane e Hugo por terem sido meus aliados nessa caminhada, por terem me ensinado a ser forte e vencer as barreiras que a vida nos impõe. Por toda dedicação e serem profissionais exemplares, a quem nunca esquecerei.

A Assistente Social Elionilde Marques, por compartilhar comigo seus conhecimentos e pela participação construtiva no meu processo de formação acadêmica. Por honrar a sua profissão acima de tudo e ser uma profissional de referência pra mim.

Ao Programa Conexões de Saberes, por toda a formação acadêmica, por todo o conhecimento compartilhado e por me fazer perceber a importância da minha história de vida e me orgulhar das minhas origens.

Aos funcionários e adolescentes da Casa de Semiliberdade do Gama pela disposição e colaboração.

À professora Maria de Fátima Castilhos Schaeffer que aceitou o desafio de me orientar, por todo o carinho e paciência, e por sempre ter se apresentado acolhedora e otimista.

Aos professores Mario Ângelo e Newton Gomes por sempre estarem dispostos a compartilhar seus conhecimentos e contribuir para o processo de qualificação. 
A todos os funcionários do Departamento de Serviço Social da Universidade de Brasília, pelo ótimo desempenho de suas funções.

A todos os meus amigos e amigas que fazem parte da minha vida e têm importância no que seu hoje. 


\section{RESUMO}

Este trabalho buscou elaborar uma reflexão sobre a cultura punitiva na prática profissional dos socioeducadores na semiliberdade no Distrito Federal por meio de um estudo de caso da Casa de Semiliberdade do Gama. Para tanto, foi realizado um resgate histórico com foco na questão do controle social de crianças e adolescentes em conflito com a lei, abordando os conceitos de Estado; hegemonia e contra hegemonia; e controle social. Este estudo conclui que, mesmo com 18 anos da promulgação do Estatuto da Criança e do Adolescente, a prática profissional dos socioeducadores não tem acompanhado as mudanças no campo legal. Isso ocorre devido a continuidade de uma cultura punitiva herdada de um sistema anterior ao ECA.

Palavras-chave: Punição; Semiliberdade; Adolescente em conflito com a lei. 


\section{LISTA DE SIGLAS}

ECA Estatuto da Criança e do Adolescente

SEJUS Secretaria de Estado de justiça, Direitos Humanos e Cidadania

SEAS Secretaria de Estado de Ação Social

CREAS Centro de Referência Especializado em Assistência Social

RA Região Administrativa

ARE Aparelho Repressivo do Estado

AIE Aparelho Ideológico do Estado

SAM Serviço de Assistência ao Menor

Febem Fundação de Bem Estar do Menor

Funabem Fundação Nacional de Bem Estar do Menor

ONU Organização das Nações Unidas

SINASE Sistema Nacional de Atendimento Socioeducativo

IBGE Instituto Brasileiro de Geografia e Estatística

SCIELO Scientific Electronic Library Online

NEV Núcleo de Estudo de Violência da USP 


\section{SUMÁRIO}

Introdução

Capítulo 1 - O percurso da punição no âmbito do controle social ....................................14

1.1 Poder e Estado ........................................................................................................14

1.2. O uso da punição como instrumento disciplinador ............................................... 18

Capítulo 2 - História do controle social das crianças e do adolescente .............................21

Capítulo 3 - o processo de transição entre o código de menores e o estatuto da criança e do adolescente

Capítulo 4 - Medida Socioeducativa de Semiliberdade .32

Capítulo 5 - A execução da Medida na Casa de Semiliberdade do Gama - DF .38

Capítulo 6 - Análise dos Dados .43

6.1 Trajetória profissional dos socioeducadores nas medidas socioeducativas .43

6.2 Quem é o adolescente que chega na semiliberdade?

6.3 Medida socioeducativa versus punição . .45

Considerações Finais .51

Referências Bibliográficas .52

Anexos .55 


\section{INTRODUÇÃO}

Desde o século XIV, os crimes cometidos por jovens e crianças vêm sendo descritos. No império, em 1830, os jovens menores de 14 anos que cometiam com discernimento atos infracionais eram obrigados à reclusão em abrigos, como forma de punição. Publicações e periódicos do fim do século passado apontavam as ruas das grandes cidades brasileiras como espaços povoados por crianças e jovens pobres, "vadias", que se expunham em delitos como furtos e roubos e eram presos em cadeias públicas como criminosos comuns ${ }^{1}$.

De acordo com vários autores que descrevem a história da proteção social à infância e juventude no Brasil, dos quais se pode citar, Fucks (2004), Faleiros (1995), Londoño (1991), Fleury (1983) relatam que no século XX surgiram os primeiros projetos legislativos que visavam proteger o infrator. Para tal, foi criado o Instituto Sete de Setembro, o qual abrigava os infratores e os desvalidos. O Brasil, a partir de 1927, tornou-se o primeiro país da América Latina a implantar um código (Código de Menores) com o intuito de oferecer medidas específicas para jovens e crianças com idade de até 18 anos.

O Código de Menores garantia que infratores com idade inferior a 14 anos não fossem submetidos a processo penal de nenhuma natureza, cabendo-lhes, assim, um processo especial. A grande inovação desse código foi estabelecer a noção de abandono, delinquiência, perda e suspensão de poder pátrio. Em 05.11.1941, com a publicação do decreto-lei n³.779, o instituto Sete de Setembro transforma-se no SAM - Serviço de Assistência ao Menor. Apresentando de forma clara, como essa proteção se expressava na realidade, ou seja: de forma punitiva e policial, não oferecendo o caráter assistencial proposto, passando a ser uma política marcada por violência física e psíquica, e sendo, desta forma, um sistema desumano, alvo de críticas de toda a sociedade (Fleury, 1983). Como solução para o problema, em 1964 foi extinto o SAM e criada a Fundação Nacional de Bem Estar do Menor (Funabem), e órgãos executores, as chamadas Febem - Fundação de Bem Estar do Menor (Fleury, 1983).

\footnotetext{
${ }^{1}$ Londoño, 1991 apud, Oliveira, Maruza B. e Assis, Simone G.
} 
A Funabem visava à migração do modelo carcerário produzido pelo SAM para um modelo terapêutico, mediante aplicação dos conhecimentos da psicologia e da pedagogia, dentre outras ciências, com o objetivo de reintegrar o indivíduo à sociedade (Fleury, 1983). A Funabem acabou sendo extinta pelos mesmos motivos que o Serviço de Assistência ao Menor - SAM, ou seja: instalações físicas insalubres e inadequadas, maus-tratos infringidos aos internos nas unidades oficiais, que iam desde a violência física e psicológica a outras ações que implicavam na perda da individualidade e na capacidade de pensar.

Várias foram as tentativas do Estado de responder a questão da criminalidade de adolescentes. Porém, a teoria não foi aplicada na realidade de forma eficiente e a conseqüência foi a exposição dos adolescentes a péssimas condições de vida e a perpetuação da vida no crime causada pela falta de condições para uma mudança de valores e pensamentos. Em situações de conflito com a lei, os adolescentes deveriam receber tratamento que resgatasse sua dignidade e os ensinasse a viver em sociedade, transformando-os em verdadeiros cidadãos.

Em 1990, com a declaração universal dos Direitos da Criança e do Adolescente da Organização das Nações Unidas (ONU), o Código de Menores de 1979 foi revogado. Em seu lugar surgiu o ECA - Estatuto da Criança e do Adolescente, que reconhece as crianças e os adolescentes $^{2}$ como pessoas em desenvolvimento, sujeitos de direito e merecedores de tratamento diferenciado e de prioridade absoluta. O ECA propiciou às crianças e aos adolescentes o direito de receber proteção do Estado sem distinção de raça, cor ou classe social, e dando a eles prioridade absoluta em políticas públicas e destinação privilegiada de recursos das diversas instâncias político-administrativas do país. O Estatuto estabelece, no artigo $\mathrm{n}^{\mathbf{0}} 104$, que menores de 18 anos são penalmente inimputáveis, mas estão sujeitos as medidas socioeducativas descritas no artigo 112: advertência; obrigação de reparar o dano; prestação de serviço à comunidade; liberdade assistida; inserção em regime de semiliberdade; e internação em estabelecimento educacional que tenha como objetivo a inserção do jovem autor de atos infracionais na sociedade e no núcleo familiar, com acompanhamento nas atividades escolares, na comunidade, na família e em serviços de saúde, dentre outros. É necessário ressaltar que a proposta de tratamento diferenciado para crianças e adolescentes já estava estabelecida pela Constituição Federal no artigo 227:

\footnotetext{
${ }^{2}$ Art. $\mathbf{2}^{\circ}$ do eca- Considera-se criança, para os efeitos desta Lei, a pessoa até 12 (doze) anos de idade incompletos, e adolescente aquela entre doze e dezoito anos de idade.
} 
"É dever da família, da sociedade e do Estado assegurar à criança e ao adolescente, com absoluta prioridade, o direito à vida, à saúde, à alimentação, à educação, ao lazer, à profissionalização, à cultura, à dignidade, ao respeito, à liberdade e à convivência familiar e comunitária, além de colocá-los a salvo de toda forma de negligência, discriminação, exploração, violência, crueldade e opressão".

A proteção do jovem autor de atos infracionais é de inteira responsabilidade do Estado, encarregado de oferecer a assistência necessária para que jovens e crianças sejam afastados de práticas contravencionais. Cabe ao Estado garantir educação, lazer, cultura, saúde e todo o aparato legal para a formação de um cidadão. A criação do ECA é uma forma de viabilizar e concretizar os direitos da criança e do adolescente.

Quando realizamos uma análise histórica, percebemos que as alterações ocorridas no campo teórico não são acompanhadas por uma mudança real, porque os adolescentes que transgridem as leis continuam sendo alvos de injustiças e maus-tratos, perpetuando uma cultura punitiva.

As reflexões que vieram à tona no decorrer do estágio supervisionado curricular, realizado no $2^{\circ}$ semestre de 2006 e também no $1^{\circ}$ semestre de 2007 , despertaram o interesse pelo objeto de pesquisa ora proposto: Educar ou Punir: dilemas na prática socioeducativa com adolescentes em regime de Semiliberdade no Gama Leste - DF.

Em 2006, o estágio supervisionado realizou-se no CREAS - Centro de Referência Especializado em Assistência Social, foi voltado para a medida socioeducativa de liberdade assistida na cidade satélite de Ceilândia. Dado o processo de transferência das medidas socioeducativas da Secretaria de Estado e Ação Social - SEAS, para a Secretaria de Justiça, Cidadania e Direitos Humanos - SEJUS, o efetivo dos funcionários passou por mudanças que refletiram no campo de estágio, obrigando sua realocação para a casa de semiliberdade, localizada no Gama Leste, Região Administrativa do Gama.

As reflexões advindas da experiência do trabalho executado na liberdade assistida e a semiliberdade, bem como os conhecimentos acumulados durante o curso sobre direitos humanos, cidadania, doutrina de proteção integral dentre outros, permitiram vislumbrar o tema proposto para a pesquisa.

Para a concretização do trabalho foi realizada pesquisa bibliográfica em fontes secundárias, visando à aproximação sucessiva sobre questões históricas relacionadas ao tema, 
a fim de fornecer suporte teórico para a segunda parte do trabalho. E, posteriormente, foi efetuada a análise dos dados coletados na pesquisa aplicada na Casa de Semiliberdade da Região Administrativa do Gama, no Distrito Federal. Para o norteamento da pesquisa, adotamos a pergunta: O Estatuto da Criança e do Adolescente conseguiu romper com a cultura punitiva introjetada no imaginário social?

As hipóteses adotadas foram:

1) Existe o reconhecimento legal de que o adolescente é um sujeito em desenvolvimento e, em conseqüência, inimputável, cabendo ao Estado e à família a sua formação social. No imaginário social, a cultura punitiva perpetuada por um longo período ainda não foi desconstruída, refletindo-se nas ações dos socioeducadores das casas de semiliberdade.

2) Os socioeducadores valem-se da punição como forma de auto-afirmação de sua autoridade e manutenção da disciplina.

O objetivo central deste trabalho é analisar, por meio do entendimento dos funcionários e dos adolescentes, se o trabalho na casa de semiliberdade ultrapassou a lógica da punição e passou, de fato, a efetuar um trabalho socioeducativo. Dessa forma, foram estabelecidos os seguintes objetivos específicos:

- Analisar, por meio de um contexto histórico, as mudanças no campo legal sobre o atendimento de adolescentes autores de atos infracionais.

- Verificar as diretrizes dispostas para a execução do trabalho do socioeducador, à luz do Estatuto da Criança e do Adolescente e do Sistema Nacional de Atendimento Socioeducativo (SINASE).

- Enfatizar a importância da desconstrução, no imaginário popular, do uso da punição como meio transformador do sujeito, para que assim haja uma real execução das medidas socioeducativas.

Na construção de um caminho teórico-metodológico, para unir dados secundários com dados primários sem a perda da cientificidade e para dar suporte à analise posterior dos dados, foram estabelecidas as seguintes categorias centrais: punição; autoridade; disciplina; hegemonia e contra hegemonia; Estado; controle social; medidas socioeducativas; adolescente autor de atos infracionais; e Estatuto da Criança e do Adolescente. 
A partir do esforço para a captação da realidade sem reduzi-la ao método e a fim de trabalhá-la considerando a sua complexidade, foi escolhida a pesquisa social qualitativa. Para a obtenção dos dados qualitativos foram realizadas entrevistas semi-estruturadas na unidade de semiliberdade do Gama Leste. Na obtenção de dados secundários recorreu-se ao Estatuto da Criança e do Adolescente e o Sistema Nacional de Atendimento Socioeducativo - SINASE.

Assim sendo, este trabalho pretende demonstrar, por meio de um estudo científico, a situação atual da questão do tratamento dispensado aos adolescentes na Região Administrativa do Gama Leste e, a partir dessa analise, facilitar a compreensão das falhas existentes na aplicação de medidas socioeducativas de semiliberdade naquela região.

Pretendemos que este estudo contribua para romper a visão arraigada da cultura punitiva, em detrimento da educativa que se estabeleceu na execução das medidas socioeducativas, em especial, da semiliberdade na unidade do Gama Leste. 


\section{CAPÍTULO 1}

\section{O PERCUSO DA PUNIÇÃO NO ÂMBITO DO CONTROLE SOCIAL}

\subsection{Poder e Estado}

Partindo dos conhecimentos de Althusser e Gramsci sobre questões que envolvem Estado e poder, pretende-se abordar fatores culturais que proporcionaram o surgimento da questão central desse trabalho, ou seja, a perspectiva em que tem sido desenvolvido o trabalho dos educadores sociais na execução da medida socioeducativa de Semiliberdade. Uma análise mais aprofundada será dada à questão a partir da apresentação de definições importantes para uma melhor compreensão do fenômeno.

Para tal, nos valemos dos estudos de Althusser, que analisam a sociedade dividida em infra-estrutura e superestrutura. No contexto, fazendo uma analogia à forma de um edifício, Althusser considera a infra-estrutura como sendo a base desse edifício, onde se centram as bases econômicas, unidades de forças produtivas e relações de produção. Já a superestrutura corresponderia aos andares desse edifício, em referência ao nível jurídicopolítico, que são o direito e o Estado, e ao nível ideológico, ao qual pertencem a religião e a moral, dentre outras (Albuquerque, 1983).

Considerando o Estado como elemento central na organização social, estudos como

os de Althusser, que afirmam ser, o Estado, o aparelho detentor do poder repressivo e ideológico com função de manter e repassar a ascendência da classe dominante sobre a classe explorada. Para Althusser, a transformação seria efetuada apenas com a destruição do Estado. Contudo, ao fazer essa afirmativa, Althusser desconsidera a possibilidade de transformação por outras vias, que não ocorram no âmbito do Estado, como as oriundas da sociedade civil.

Althusser considera Estado, aparelho de Estado e aparelho repressivo do Estado como sinônimos e que, ao falar-se em Estado, não se está envolvendo apenas o aparelho especializado, restrito, como o chefe de Estado e o Governo, mas também outras instituições como o Exército, polícia, os tribunais e as prisões. O autor, no entanto, faz distinção entre aparelho de Estado e poder de Estado, ao considerar que é o segundo que define o primeiro, já que a luta de classes gira em torno da tomada e manutenção do poder de Estado "por uma 
certa classe, ou por uma aliança de classes ou de frações de classe”. (Albuquerque, 1983 p. 24).

Os clássicos do marxismo, em sua prática política, analisam a questão do Estado com uma maior complexidade do que a definição colocada pela teoria marxista. $\mathrm{O}$ aparelho (repressivo) de Estado, tal como é abordado na teoria marxista, compreende ao exército, polícia e prisões, dentre outros, que fazem uso da violência, física ou não, em situações limite.

Louis Althusser desenvolve ainda o conceito de Aparelho ideológico do Estado AIE, para explicar a construção da ideologia dominante além dos instrumentos de repressão do Estado, como pela submissão de classes por meio do convencimento. Nessa perspectiva, os aparelhos repressivo do Estado - ARE caracterizam-se por manter seu funcionamento à base da violência, enquanto os aparelhos ideológicos tem como base a manutenção da ideologia . Para isso existem instituições como: o sistema das diferentes igrejas; o sistema político; escolar (públicas e particulares); familiar; sindical; sistemas da informação (imprensa, rádio, televisão, dentre outros) e cultural (literatura, artes, esportes, dentre outros), que fazem esse papel de aparelho ideológico, utilizados para a formação de uma cultura hegemônica em uma sociedade.

Cabe ressaltar que o ARE - aparelho repressivo do Estado, não é totalmente repressivo, assim como o AIE não é totalmente ideológico. A ideologia também se faz presente no ARE e a repressão, da mesma forma, se faz presente nos aparelhos ideológicos do Estado. Tanto o AIE quanto o ARE possuem o objetivo de garantir, pela força física ou ideológica, as condições políticas da reprodução das relações de produção. (Albuquerque, 1983).

Outros autores, como Gramsci, percebem que na sociedade capitalista madura o Estado se ampliou e os problemas relativos ao poder tornaram-se complexos, fazendo emergir uma nova esfera, a "sociedade civil", tornando mais complexas as formas de estruturação das classes sociais e sua relação com a política. É nesse contexto que indica as possibilidades de construção de uma nova sociabilidade, de transformação das condições de vida das classes subalternas, passando necessariamente pela construção de uma nova hegemonia, cujo processo de estruturação não ocorre somente a partir do campo econômico. Isso se dá porque Gramsci tem a clara compreensão de que a estrutura da sociedade é fortemente determinada por idéias e valores, na luta pela hegemonia. 
Para Gruppi (1991), ao trabalhar o conceito de Estado Ampliado, Gramsci afirma que o Estado é um aparelho permeado por correlações de forças entre classe dominante e classe dominada (atuando como sociedade civil organizada), e o resultado dessa correlação seriam as mudanças e/ou transformações sociais.

O conceito de sociedade civil organizada parte do pressuposto de que a classe explorada pode se organizar e expressar suas demandas institucionalmente. Porém, isso requer uma organização social que envolveria um processo político e cultural de conscientização, politização e organização da classe explorada na criação de alternativas para superar a ideologia dominante, deslegitimando a ordem burguesa (Gruppi, 1991). Temos, então, os conceitos de hegemonia e contra-hegemonia, em Gramsci, como base para estruturar essa discussão.

Hegemonia pode ser definida como a junção de determinadas formas de pensar que se apresentam como resolução de um problema e formam um consenso social. Logo, a classe dominante opera de modo a manter sua hegemonia como dominante por meio de canais como escola, igreja, cinema, radio e outros, conseguindo assim, camuflar seus reais objetivos (trabalho ideológico) conquistando bases sociais que a legitimem (Gruppi, 1991).

Para Gramsci a sociedade civil possui condições de se manifestar, porém, o faz de forma desorganizada e fragmentada, se valendo apenas da força, e somente dela. Diante dessa realidade surge a precisão de um trabalho cultural e político que desvende a real condição do sujeito explorado e o torne ser social, construtor da própria história, formando assim, uma classe em si e para si (Gruppi, 1991). Dessa forma, surgem duas figuras centrais nesse processo: os intelectuais, vistos como agentes capazes de conscientizar e politizar as massas populares, e os partidos políticos que tem o papel de organizar as massas populares concretizando a formação de uma contra-hegemonia e difundindo-a socialmente para se tornar hegemônica.

A contra-hegemonia aparece como a possibilidade de transformação da classe explorada em classe dominante, quando as forças sociais organizadas dentro da sociedade civil, pela luta política, passam a compor o Estado e assumem viés de força política (Gruppi, 1991).

O processo de formação de uma contra-hegemonia também se dá fora do aparelho de Estado, revelando assim que o poder também se expressa nessa contra-hegemonia, envolvendo 
a dimensão cultural e política do poder, sobressaindo-se em várias esferas, tanto da microestrutura quanto da macro-estrutura social (Gruppi, 1991).

Essa transição do momento econômico-corporativo ao ético-político significa, também, levar em conta o processo de correlação de forças sociais, que implica a passagem da estrutura para as superestruturas mais complexas; é a fase na qual as ideologias anteriores se tornam 'partido', colocando-se em confronto e entrando em luta, até que somente uma delas ou uma combinação de ideologias tende a prevalecer e a difundir-se sobre toda a área social, determinando, além da unidade econômica e política, a unidade intelectual e moral, mediante um plano não corporativo, mas 'universal', criando, assim, a hegemonia de um grupo social fundamental sobre os grupos subordinados (Gruppi, 1991).

Desta forma, constituir-se como classe hegemônica significa tornar-se protagonista das reivindicações de outros estratos sociais, de modo a unir em torno de si esses estratos e realizar com eles uma aliança na luta por interesses comuns.

Hegemonia é, assim, por um lado, vontade coletiva, e, por outro, autogoverno. Esse último se alcança através de um trabalho gradativo, que incorpora o singular ao coletivo e que, nesse processo, não mantém os grupos subalternos no plano inferior, mas os eleva, torna-os mais capazes de dominar as situações, confere-lhes uma maior universalidade, o que significa, para Gramsci, a realização de uma "reforma intelectual e moral”. (Gruppi, 1991 p.72).

Gramsci se reporta à hegemonia como "direção intelectual e moral" afirma que essa direção também se exerce no campo das idéias e da cultura, manifestando a capacidade de conquistar o consenso e de formar uma base social, pois "A hegemonia, portanto não é apenas política, mas é também um fato cultural, moral, de concepção do mundo" (Gramsci apud Gruppi, 1991 p. 73).

Fazendo o uso das análises apresentadas no estudo da sociedade, temos que o controle exercido pelo Estado reforça a hegemonia da classe dominante, o que representa uma forma de exercer poder. Porém o Estado não é o único a exercê-lo. A sociedade civil também pode desempenhar o poder quando forma um contra-poder, por exemplo, os Movimentos sociais que disputam forças para tornarem-se contra-hegemonia visando transformar-se na hegemonia dominante. Isso denota que desde que esteja organizada, a sociedade civil tem forças para disseminar uma contra-hegemonia. 


\subsection{O uso da punição como instrumento disciplinador}

Foucault elaborou um estudo sobre as transformações das práticas penais ocorridas na França durante o século XIX. O autor aborda a questão sobre o por quê do sistema prisional se tornar à pena por excelência, excluindo do meio da sociedade o suplício ou o castigo simbólico que até o século XVIII era usado como forma de punição e controle social.

Os medievos sistemas punitivos europeus tinham como legítima uma grande variedade de penas corporais, dentre elas, o suplício, conhecido como uma "arte de fazer sofrer", que se tratava de uma pena corporal dolorosa baseada na proporção entre quantidade de sofrimento e a gravidade do crime. Esses espetáculos punitivos eram impostos àqueles que transgredissem as leis impostas, sendo submetidos a espetáculos públicos de tortura. Os corpos dos sentenciados eram marcados, esquartejados, expostos vivos ou mortos para o resto da população como demonstração do poder eclesiástico (feudalismo) ou então o poder real (absolutismo).

Na segunda metade do século XVIII a sociedade passa a discutir novas formas de reprimir aqueles que transgredissem as leis, normas ou valores impostos. O suplício, após anos de aplicação, é contestado em sua eficácia, uma vez que o condenado, sendo posto de frente ao carrasco, desperta no povo o sentimento de compaixão e piedade, enquanto a figura do carrasco se assemelha a de um criminoso. O suplício, além de fazer essa inversão de papéis, foi percebido como um ato incentivador da violência, à medida que o povo compreendia "o fazer justiça" como ato de derramar sangue, (Foucault, 1987).

No regime absolutista, o poder era concentrado em um poder judiciário central subordinado à figura do rei, sendo que todo ato ilícito praticado seria um ato contra esse poder centralizado, ameaçando o ilimitado poder real. Surgem, então, filósofos e juristas que se opõem a essa prática (Foucault, 1987). Na época das luzes, o Iluminismo corrobora para a propagação dos ideais "humanitários", ou seja, percebe-se a necessidade de "punições menos diretamente físicas, uma certa discrição na arte de fazer sofrer, um arranjo de sofrimentos mais sutis, mais velados e despojados de ostentação" (Foucault, 1987 p. 12).

Nesse período, a sociedade passa por momentos de transformação, pois, devido ao crescimento do sistema capitalista, a ilegalidade dos bens passa a ter maior importância do que a ilegalidade do corpo, ocasionado uma mudança de valores onde os bens, a propriedade 
privada, passa a ser uma questão central e de suma importância dentro da sociedade. No contexto, tornam-se mais evidentes as características do capitalismo, como concentração de renda, propriedade privada e a divisão da sociedade em classe. O suplício já não corresponde de forma eficiente aos seus objetivos. Há lacunas no sistema penal, que é dividido em múltiplas instâncias, "por sua própria superabundância, se neutralizam e são incapazes de cobrir o corpo social em toda sua extensão" (Foucault, 1987 p. 67). Diante de várias manifestações de oposição ao uso do suplício, a punição deixa aos poucos de ser uma cena e surge o que Foucault chama de "sociedade disciplinar".

No sistema capitalista, as prisões se transformam na principal forma de punir porque trabalham com a noção de disciplina, cujos elementos são: a) distribuição dos corpos, de acordo com as funções predeterminadas; b) o controle da atividade individual, pela reconstrução do corpo como portador de forças dirigidas; c) a organização das gêneses, pela internalização/aprendizagem das funções; d) a composição das forças, pela articulação funcional das forças corporais em aparelhos eficientes (Foucault, 1987).

Tomando por base o método de adestramento dos corpos, Foucault descreve o emprego da disciplina no controle social, com técnicas de um sistema duplo de recompensa (promoção) e punição (degradação), e de vigilância hierárquica, o processo que seria, técnicas de hierarquia (vigilância) com técnicas de normalização (sanção), a constitui-se uma nova forma de punir, e assim controlar os indivíduos (Foucault, 1987).

A prisão conseguiu levar o caráter humanitário para a punição, tendo em vista duas características: 1 - a privação da liberdade, onde o indivíduo perde o seu maior bem, a liberdade. A prisão permite fazer uma quantificação da pena de acordo com o tempo. Tirando o tempo, o criminoso estaria reparando seu dano perante a sociedade. Daí a expressão "pagar sua dívida" (Foucault, 1987); 2 - trata-se de um aparelho para transformar os indivíduos. A prisão possui uma função técnica de correção, por meio do poder exercido sobre os indivíduos presos usando-se mecanismos internos de repressão e de castigo, ou seja, disciplina despótica.

Dessa forma, o sistema prisional foi substituído e posto como a principal forma de punição. Considerado um sistema eficiente e adequado, as prisões ganham legitimidade perante o Estado e a sociedade, sendo até hoje o sistema legal e primordial usado como punição para aqueles que não seguem as normas impostas pela sociedade. Isso permite a 
legitimação da punição como instrumento para se alcançar a disciplina e, por fim último, manter o controle social. 


\section{CAPÍtULO 2}

\section{HISTÓRIA DO CONTROLE SOCIAL DAS CRIANÇAS E DO ADOLESCENTE}

Estudos históricos efetuados na área da infância e da adolescêencia, entre os quais podemos citar Aries (1986), apontam que a categoria infância nem sempre foi entendida tal como é hoje ${ }^{3}$, ou seja, sujeitos de direitos, em desenvolvimento e com prioridade absoluta. Após a independência física, a criança passava imediatamente a ser compreendida como um adulto. A centralidade familiar passa a ser em torno da criança. Até então a criança tratava-se de um adulto em desenvolvimento (Aries, 1986,P).

De acordo com Áries (1986), partindo de um enfoque histórico, a categoria infância é resultado de uma complexa construção social cuja finalidade é atender as condicionantes estruturais e as sucessivas mudanças no campo dos sentimentos.

Dessa forma, juntamente com a criação da categoria infância é formada uma categoria de indivíduos frágeis, cuja proteção ultrapassa a noção de direito e passa ser um mecanismo de controle social. No século XVIII, percebe-se a escola como um mecanismo de "produção da ordem e homogeneização da categoria criança" (García, 1994 p. 16), enquanto que no século XIX, utilizam-se outros mecanismos para atingir aqueles que estão fora do sistema escolar, o que foi o marco de uma mudança fundamental na história do controle penal infantil. Juntamente com o reconhecimento dessa classe de indivíduos frágeis, surge a ligação entre pobreza e delinqüência, sendo necessário estabelecer uma proteção/controle dessa parcela da população (García, 1994).

Durante o século XIX, vários países adotavam medidas diferenciadas na determinação da sentença entre os "menores delinquentes" e os adultos. Na suíça, em 1872, assim como no código penal alemão de 1871, era estabelecida uma idade limite para a criança ser considerada inimputável (García, 1994). Torna-se importante ressaltar que as transformações ocorridas no campo de leis voltadas a "menores delinqüentes" surgem e desenvolvem-se em um processo

\footnotetext{
${ }^{3}$ No Estatuto da Criança e do adolescente, o Art. $2^{\circ}$ define criança sendo aquela pessoa com idade inferior a 12 anos já adolescente corresponde aquela pessoas com idade superior a 12 anos e inferior a 18. Aspectos sociais e psicológicos não são levando em consideração.
} 
de constante confusão, sendo ainda imatura uma análise mais aprofundada sobre o tema (García, 1994). Nesse processo, é perceptível a tendência do aumento da idade da responsabilidade penal para atingir o total afastamento das crianças do sistema penal de adultos, assim como a criação de penas específicas para "Menores".

Nesse período, século XIX, políticas de segregação de menores começam a ganhar legitimidade, tendo como base a corrente teórica positivista, além de outras que atuam na esfera social. Conforme explica García (1994), o crescente interesse na preservação da integridade da criança se encontrava em prevenir futuros "adolescentes-delinqüente".

Nesse período, século XIX era perceptível a confusão existente entre pobreza, delinqüência, abuso e maus-tratos. A clarificação desses conceitos e o reconhecimento do abuso e dos maus-tratos como um problema grave e de responsabilidade da esfera pública se dá a partir de 1990, mediante a implantação do Estatuto da Criança e Adolescente. (García, 1994).

Durante muito tempo o uso da agressão à criança foi legitimado como meio de estabelecer a obediência, disciplina e educação. Essa lógica construída no imaginário popular pode ser estendida aos dias atuais, onde é comum e visível essa prática para manutenção da ordem e controle social. Exemplo disso foi o fato da FEBEM - Fundação Estadual do BemEstar do Menor, em 2003, ter sido denunciada pela anistia internacional como sendo ambiente de tortura. Em 2004 as FEBENS de Tatuapé e Vila Maria, São Paulo, foram alvo de denúncias pelo o Conanda - Conselho Nacional dos Direitos da Criança e do Adolescente. Assim, várias são as denuncias de tortura, maus-tratos e atitudes que violam os direitos das crianças e adolescentes sendo usadas como meio de controle.

Durante o século XX, no Brasil, a partir de 1923, cresce o número de países que utilizam os Tribunais de Menores como meio de controle social para crianças e adolescentes. A idéia de criação de Tribunais voltados para criança e adolescentes ganhou a hegemonia por meio de sua divulgação em congressos internacionais, onde a questão de menores delinqüentes era discutida. Segundo García (1994), o primeiro Congresso Internacional de Menores, que ocorreu em Paris entre os dias 29 de junho e 1 de julho de 1911, é um documento central para uma reconstrução histórica. Isso se deve à grande adesão de países participantes, ou de sua representatividade no mundo político-judicial, e por ter abordado temas contundentes de forma sistemática, que continuam sendo atuais, sobre a questão menor "abandonado-delinqüente". 
Sendo assim, há dois grandes motivos que levaram à realização de reformas no campo do atendimento a crianças e adolescentes

\footnotetext{
"As espantosas condições de vida nos cárceres, onde as crianças eram alojadas de forma indiscriminada com os adultos, e a formalidade e inflexibilidade da lei penal, que obrigando o respeito, entre outros, aos princípios de legalidade e de determinação da sentença, impediam a tarefa de repressão-proteção própria do direito de menores" (García, 1994 p.19-20).
}

Essa necessidade de mudanças na área infanto-juvenil diz respeito à necessidade da adaptação das leis vigentes para uma dada realidade, onde o controle das violações cometida por crianças e adolescentes se faz necessário para o controle da ordem. Com os estudos desenvolvidos pela psicologia, sociologia entre outras ciências, a sociedade começou a perceber essa faixa etária como um grupo em desenvolvimento e com especificidades próprias, tornando importante a adoção de medidas especificas para esse público. Porém, a punição continua sendo o meio utilizado para alcançar o objetivo de manter a disciplina, pois como afirma Foucault "a certeza de ser punido é que deve desviar o homem do crime" (Foucault, 1987 p.13). Esse raciocínio segue a lógica da punibilidade como instrumento de mudança de comportamento.

Ao perceber que a criança "delinqüente" e "abandonadonada" representa um perigo para a manutenção do controle social, no inicio do século $\mathrm{XX}$, o Brasil cria os tribunais para “Menores”, cuja resposta, não foi suficiente para controlar possíveis infratores (García, 1994).

Em 1923, o Brasil e outros países implantaram os tribunais de menores para responder à questão dos "menores" (García, 1994). Esse movimento de oferecer um atendimento diferenciado para "Menores" em conflito com a lei cresce em vários países da América latina no mesmo período. Isso denota o reconhecimento de que crianças e adolescentes possuem particularidades que os diferenciam dos adultos, sendo, portanto, necessário um atendimento diferenciado para esse segmento da sociedade.

Segundo a visão da época, os Tribunais para Menores foram criados "pela saúde física da raça, por sua saúde moral, pelo porvir das novas gerações, pela grandeza da pátria; é indispensável cuidar a colheita humana e prestar à infância a atenção que merece..." (Arenaza, 1927 p. 36 apud García, 1994 p. 24) Isso demonstrou a preocupação do Estado com relação à questão da delinquiência infanto-juvenil, já que se tratava de um problema do presente que 
representava o futuro da nação. Sendo, dessa forma, necessária à manutenção do controle social de menores como garantia de ordem na sociedade.

Essa necessidade de controle social ocorre, a partir do momento em que a delinqüência cometida por "Menores" é percebida como uma ameaça ao que Durkheim coloca como integração social, ameaçando a coexistência pacifica entre os indivíduos.

Durkheim coloca que essa integração social se estabelece por meio das formas de solidariedade social que efetivamente prendem os elementos ao grupo, destacando:

- $\quad$ Solidariedade Mecânica: o principio das semelhanças - típica das sociedades pré-capitalistas, na qual o individuo está diretamente ligada à sociedade, pois as pessoas ainda não se diferenciam. Forma-se um conjunto mais ou menos organizado de crenças e sentimentos comuns a todos os componentes da sociedade; (Galliano, 1986).

- $\quad$ Solidariedade Orgânica: o Principio da Diferenciação - típica das sociedades capitalistas, a qual se estabelece por meio da divisão do trabalho. $\mathrm{Na}$ solidariedade orgânica os indivíduos não se assemelham, eles se diferenciam e tornam-se interdependentes, o que faz garantir a união social. A divisão do trabalho gera, portanto, a solidariedade entre os homens (Galliano, 1986).

Diante disso, o Estado busca formas de manter essa integração e assim garantir um certo "equilíbrio" na sociedade. O tribunal de Menores surgiu para coibir o problema de delinqüência de "menores", a fim de não comprometer o futuro da sociedade. Os valores comuns que formam o coletivo seriam regulamentados e as instituições teriam como função, por meio da coerção, de manter a ordem, ou seja, evitar que as normas fossem desrespeitadas, uma vez que o desvio de comportamento é percebido por Durkheim como algo interno do sujeito (patologia), requerendo o afastamento e tratamento do mesmo para só então reintegrálo (Galliano, 1986).

Os Tribunais estabelecem uma forma de lidar com a temática infância e adolescência por um enfoque de proteção como uma forma de controle repressivo, o que traz problemas quando se trata de "Menores" vitimas de abandono tanto material quanto moral. Segundo Emílio García (1994), esse fato trouxe como consequiência a flexibilização no âmbito dos tribunais de Menores. Com a finalidade de eliminar distinções entre menores delinqüentes 
e menores abandonados, formalidades jurídicas foram sendo retiradas para garantir a eficácia das tarefas de "proteção-repressão" (García, 1994, P 25). Sendo assim, não bastava a criação de Tribunais para menores, mas se fazia necessário todo um conjunto de medidas que permitissem responder de forma eficaz os problemas que envolviam o público infanto-juvenil. Exemplo disso seria o aumento da parcela da população a ser protegida e a designação de juizes especializados para o atendimento.

O processo de eliminação de formalidades judiciais para o atendimento de crianças e adolescentes teve como base o prisma do positivismo dominante nesse período, o qual tornou possível a percepção da realidade de forma racional e controlável, reconhecendo como infrator uma categoria de indivíduos frágeis que os instrumentos científicos permitiam detectar como delinqüentes em potencial.

Essas crianças e adolescentes autores de atos infracionais ou abandonados, classe de indivíduos frágeis vistas como "anormalidades", eram classificadas cientificamente como anormais e delinqüentes em potencial, cabendo ao Estado segregar esses indivíduos para que não comprometessem o funcionamento da sociedade.

Dessa forma, no campo legal foram criadas várias leis com a finalidade de atender as demandas postas pelo público infanto-juvenil, porém sempre perpassada pela intencionalidade de controle social. Dentre essas leis pode-se citar o primeiro código de menores criado em 1927, conhecido como código Mello Mattos e um novo código de menores de 1979, que revigorou até 1990 com a promulgação do Estatuto da criança e do adolescente.

A história da infância e da adolescência se trata da história do seu controle. Utilizase da punição para que normas e regras sejam cumpridas. É perceptível que o controle social de crianças e adolescentes está relacionado ao controle dos corpos, tal como abordado por Foucault: "em qualquer sociedade, o corpo está preso no interior de poderes muito apertados, que lhe impõem limitações proibições ou obrigações" (Foucault, 1987 p. 118), o que promove, um adestramento dos corpos para o cumprimento das regras e normas estabelecidas na sociedade. 


\section{CAPÍTULO 3}

\section{O PROCESSO DE TRANSIÇÃO ENTRE O CODIGO DE MENORES E O ESTATUTO DA CRIANÇA E DO ADOLESCENTE}

Durante os anos 1980, o Brasil sofreu grandes transformações na área de atendimento a crianças e adolescentes, o que ocasionou a formulação do Estatuto da Criança e do Adolescente - ECA, aprovado pela Lei Federal n 8.069, de 13 de julho de 1990, pelo Congresso Nacional e sancionado pelo Presidente da Republica. Conforme o art. $1^{\circ}$ dessa Lei, trata-se da proteção integral á criança e ao adolescente.

A promulgação do estatuto substitui o Código de Menores de 1979 (lei 6.697), invalidando a lei 4.518, de 1964, a qual dispunha sobre a Política Nacional de Bem-Estar do Menor - PNBEM. O ECA é composto por 267 artigos, sendo que do artigo 259 ao 257, o Estatuto trata das disposições finais e transitórias. Com o Estatuto, rompe-se com a doutrina da “situação irregular", substituindo-a pela doutrina da "proteção integral". Segundo García (1994 p. 53-54), há um consenso internacional de que essa doutrina é formada por quatro instrumentos básicos:

1) Convenção Internacional das Nações Unidas sobre os Direitos da Criança;

2) Regras Mínimas das Nações Unidas para a Administração da Justiça de Menores (Regra de Beijing);

3) Diretrizes das Nações Unidas para a Prevenção da Delinqüência Juvenil;

4) Regras Mínimas das Nações Unidas para a Proteção dos Jovens Privados de Liberdade.

O ECA trouxe muitas inovações no campo do atendimento, da promoção e da defesa dos direitos à infância e à juventude.O ECA tornou-se lei de referência mundial e transformou a imagem do país no exterior quanto ao respeito e promoção dos direitos das crianças e adolescentes. Dentre inovações promovidas pelo ECA pode-se destacar:

- O artigo 88 inc. I do ECA que prevê: descentralização do poder devido ao equilíbrio entre os recursos financeiros oriundos da União e dos Estados. Cabe aos municípios a responsabilidade pelo atendimento e a municipalização da política de atendimento direto. 
- Eliminação de formas coativas de reclusão devido ao desamparo social, ficando claros no artigo 106 os motivos para a privação da liberdade. Trata-se da "essência de qualquer regime democrático a garantia dos direitos da liberdade física de todos os indivíduos" (Liberati, 1991 p 49).

- Participação paritária e deliberativa entre sociedade civil e governo. (artigo 88 inc. II do ECA)

Para Silva, (2005) o rompimento da tradição "minorista" está embasado pela dinâmica estabelecida entre três grandes atores no Brasil, da década de 1980: os movimentos sociais, as políticas públicas e o mundo jurídico. A revolução promovida pelos três setores tornou possível, no Brasil, a superação da percepção latino-americana de menor, trazendo à tona um novo olhar sobre a questão infanto-juvenil na perspectiva de sujeito de direito.

O Brasil passa por significativas transformações no período de 1946 a 1964, mediante o encerramento da democracia. Dentre elas está o advento da ditadura militar, onde as necessidades sociais passaram a ser atendidas a partir dos impactos provocados na área econômica ou da racionalidade tecnocrata, (García, 1994). Diante desse contexto, os gastos sociais passam a ter a finalidade de fortalecer determinados segmentos do setor empresarial e atender necessidades básicas dos segmentos mais rentáveis da sociedade, (García, 1994).

Nesse período a área de atendimento aos direitos das crianças e adolescentes foi marcada por duas leis:

A) A lei 4.513/79, conhecida como Código Nacional de Bem-Estar do Menor;

B) A lei 6.697/79, conhecida como o Código de Menores, que dizia respeito à proteção e vigilância aos menores em situação irregular.

Estas duas leis eram direcionadas às crianças e adolescentes que se encontravam em situação irregular, caracterizada por uma das seis situações abaixo, descritas no artigo $2^{\circ}$ do código de Menores ${ }^{4}$ :

\footnotetext{
"I - privado de condições essenciais à sua subsistência, saúde e instrução obrigatória, ainda que eventualmente, em razão de:

a) falta, ação ou omissão dos pais ou responsáveis;

b) manifesta impossibilidade dos pais ou responsável para provê-las; ou responsáveis;

II - vítima de maus-tratos ou castigos imoderados impostos pelos pais
}

\footnotetext{
${ }^{4} \mathrm{O}$ código de Menores considera "Menor" todo aquele menor de 18 anos de idade.
} 


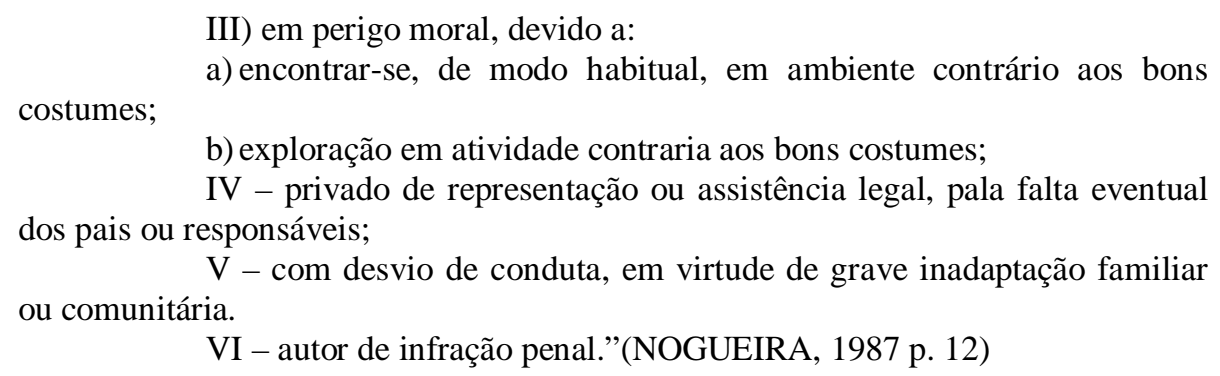

Dessa forma, o Código de Menores não contemplava crianças e adolescentes que não pertenciam a esse grupo, caracterizando uma situação que Fleury denomina de cidadania invertida, ou seja: "Trata-se, portanto de uma relação de cidadania invertida, já que o indivíduo passa a ser beneficiário do sistema pelo motivo mesmo do reconhecimento de sua incapacidade de exercer plenamente a condição de cidadão" (Fleury, 1983 p. 44).

Para que o individuo passasse a ter uma relação com o Estado, para que suas necessidades fossem supridas, fez-se necessário seu reconhecimento como "não cidadão". Independente de sua situação, toda criança e adolescente deve gozar de proteção, oportunidade e facilidades, a fim de que lhe seja proporcionado o desenvolvimento físico, mental, moral, espiritual e social, sem para que isso seja necessário estar em uma situação que até então era chamada situação irregular.

Dessa maneira, as crianças e adolescentes em situação de pobreza tornavam-se alvos em potencial de intervenção estatal. Além do código de menores, havia um conjunto de medidas que se destinava, indiferentemente, ao menor carente, ao abandonado e ao infrator: a PNBEM (política nacional de bem-estar do menor), que estabelecia para todo o país uma gestão centralizadora e verticalizada, "baseada em padrões uniformes de atenção direta implementados por órgãos executores inteiramente uniformes em termos de conteúdo, método e gestão" (Costa, 1994 p.128). A PNBEM tinha como órgão executor, em nível nacional, a Fundação Nacional de Bem-Estar do Menor (FUNABEM) e, em nível Estadual, a Fundação Estadual de Bem-Estar do Menor (Febem).

Nesse momento, ganha evidência uma nova forma de entender e intervir nessa realidade. Há uma mudança do enfoque correcional-repressivo para um enfoque assistencialista. O "Menor" deixa de ser percebido como uma ameaça social e passa a ser visto como um carente, um anormal. 
Nesse período têm-se como modelo de normalidade as crianças e adolescentes da classe média, o que faz do menor que não se enquadra nesse padrão um carente bio-psicosocio-cultural (Costa, 1994), cabendo ao Estado suprir tudo aquilo que the foi negado no âmbito das relações sociais.

Apesar dessa mudança de perspectiva, a Funabem e as Febem herdam do órgão antecessor prédios, equipamentos, matérias e os funcionários. A FUNABEM e as Febem herdaram a cultura organizacional dos antigos órgãos, fazendo com que, na realidade, o modelo correcional-repressivo nunca fosse superado, perpetuando as mesmas práticas que levaram a extinção do Serviço de Atendimento ao Menor (SAM) (Costa, 1994). De acordo com Costa (1994), "O modelo assistencialista conviveu, durante toda a sua vigência hegemônica com as práticas repressivas herdadas do passado" (Costa, 1994).

O processo de redemocratização do Brasil, no final da década de 1970, e o movimento de educação progressista, provocam um declínio da perspectiva de Menor carente para uma visão que percebe a criança e o adolescente como sujeitos de sua história e da do seu povo, tendo múltiplas possibilidades para o seu futuro. No entanto, essas mudanças de percepção da criança e do adolescente não foram suficientes para romper com a prática do passado, correcionais-repressivos. As Febem e a Funabem passaram a conviver com esses enfoques e práticas de forma justapostas, sendo eles o modelo correcional-repressivo, assistencialista e o educativo (Costa, 1994).

$\mathrm{Na}$ segunda metade dos anos 1970, o ciclo "apreensão/triagem/rotulação/reportação e confinamento" passa a ser questionado, recebendo repúdio ético e político por alguns setores da sociedade preocupados com a questão dos direitos humanos. Torna-se evidente a perversidade desse ciclo e sua deficiência quanto aos resultados (Costa, 1994).

Um olhar sobre a questão da infância e da adolescência brasileira levou ao reconhecimento de que era necessário banir as categorias estigmatizantes do Código de Menores (situação irregular) e da Política Nacional de bem-estar do Menor - PNBEM. A partir da década de 80, os movimentos sociais começam a reunir forças sobre as discussões da conversão internacional dos direitos da criança, implantando uma dimensão jurídica sobre a questão da infanto-adolescência nas ações dos movimentos sociais (García, 1994). 
Os movimentos sociais interferiram na inclusão na constituição de 1988 dos princípios básicos contidos na convenção internacional, o. que culminou na elaboração do Estatuto da Criança e Adolescente-ECA, em 13 de julho de 1990, Lei Federal no 8.069.

\footnotetext{
"É dever da família, da sociedade e do Estado assegurar à criança e ao adolescente, com absoluta prioridade, o direito à vida, à saúde, à alimentação, à educação, ao lazer, à profissionalização, à cultura, à dignidade, ao respeito, à liberdade e à convivência familiar e comunitária, além de colocá-los a salvo de toda forma de negligência, discriminação, exploração, violência, crueldade e opressão" (CF Art 227)
}

O ECA revolucionou o direito infanto-juvenil, adotando a doutrina da proteção integral (art $1^{\circ}$ do Estatuto), percebendo a criança e o adolescente como indivíduos em desenvolvimento (artigos 121 a 125), tornando necessária uma proteção diferenciada, especializada e integral.

O Estatuto da Criança e do adolescente traz o paradigma de proteção integral, pois está de acordo com a Constituição em seu Artigo 227, garantindo os direitos fundamentais a toda criança e adolescente. A introdução desse paradigma fez o ECA contrapor à teoria do direito tutelar do Menor, que era adotada pelo Código de Menores. Essa teoria considerava crianças e adolescentes alvos de medidas judiciais quando constatado sua situação irregular (Liberati, 1991).

O Estatuto está direcionado, assim, ao desenvolvimento das crianças e adolescentes garantindo, para tanto, seus direitos fundamentais: "Os mesmos direitos de qualquer pessoa humana, tais como o direito à vida e à saúde, à educação, à liberdade, ao respeito e à dignidade, à convivência familiar e comunitária, à cultura, ao lazer e ao esporte, à profissionalização e à proteção no trabalho. Esses direitos são garantidos na Constituição Federal (Art. 5) e consignados no Estatuto".(Liberati, 1991 p. 4).

A terminologia "Menor", designada a pessoas menores de 18 anos, foi impregnada por um caráter estigmatizante. O Código de Menores caracterizou o termo como sinônimo de carente, abandonado, delinqüente, infrator. (Liberati, 1991), atribuindo uma rotulagem e estigma ao nome e aqueles que assim eram designados.

O Artigo $2^{\circ}$ do ECA, diz: "Considera-se criança, para os efeitos dessa lei, a pessoa até doze anos de idade incompletos, e adolescentes aquela entre doze e dezoito anos de idade". 
Essa distinção entre criança e adolescente é fundada apenas pela questão da idade, não considerando fatores psicológicos ou/e sociais. Porém, como está estabelecido no parágrafo único do Artigo $2^{\circ}$ do Estatuto, em casos excepcionais expressos nessa lei, sua aplicação pode estender a faixa etária de 18 a 21 anos de idade incompletos.

Outra característica importante do ECA a ser ressaltada é a ênfase dada a absoluta prioridade às criança e adolescentes.

"É dever da família, da comunidade, da sociedade em geral e do poder público assegurar, com absoluta prioridade, a efetivação dos direitos referentes à vida, à saúde, à alimentação, à educação, ao esporte, ao lazer, à profissionalização, à cultura, à dignidade, ao respeito, à liberdade e à convivência familiar e comunitária Parágrafo único. A garantia de prioridade compreende:

a) primazia de receber proteção e socorro em quaisquer circunstâncias;

b) precedência de atendimento nos serviços públicos ou de relevância pública;

c) preferência na formulação e na execução das políticas sociais públicas;

d) destinação privilegiada de recursos públicos nas áreas relacionadas com a proteção à infância e à juventude." (Art. 4 do ECA).

O público infanto-juvenil deve ter prioridade absoluta nas ações governamentais. Dessa forma, o Estatuto não apenas enumera os direitos da criança e do adolescente, mas indica caminhos para seu cumprimento quanto ao caráter de prioridade absoluta. 


\section{CAPITULO 4}

\section{MEDIDA SOCIOEDUCATIVA DE SEMILIBERDADE}

Ao estabelecer na Carta Constitucional a prioridade absoluta para crianças e adolescentes, regulamentando no Estatuto que as protege os princípios do artigo 227, da Constituição Federal, criou-se um instrumento adequado para o enfrentamento das questões que envolvem as crianças e adolescentes a fim de suprir suas necessidades. Reconhece os menores de 18 anos como sujeitos de direitos em condição peculiar de desenvolvimento e de prioridade absoluta (artigos $3^{\circ}, 4^{\circ}, 5^{\circ}$ e $6^{\circ}$ do ECA). Os adolescentes que cometem atos infracionais, submetidos ao estatuto da criança e do adolescente, passam a receber um tratamento diferenciado dos adultos, conforme o artigo 228 da Constituição Federal.

Segundo o Estatuto da Criança e do Adolescente, verificada a prática do ato infracional $^{5}$, a autoridade competente poderá aplicar ao adolescente uma das seis medidas socioeducativas que correspondem à advertência, obrigação de reparar danos, prestação de serviços à comunidade, liberdade assistida, semiliberdade, internação (Artigo 112-ECA). Logo que houver a definição sobre a aplicação da medida, a autoridade levará em conta a capacidade do adolescente em cumpri-la, as circunstâncias e a gravidade da infração (CMDCA, 2000).

A semiliberdade é uma das seis medidas socioeducativas previstas no Estatuto da Criança e do Adolescente e tem a finalidade de promover, no âmbito sócio-familiar, os jovens entre 12 e 18 anos que cometeram ato infracional. É fixada em um prazo mínimo de seis meses, podendo ser prorrogado, revogado ou substituído por outra medida. A semiliberdade pode ser aplicada como medida inicial, evitando-se o confinamento total do socioeducando em uma instituição, ou como forma de progressão de regime, para aqueles que já se encontram privados de liberdade.

No cumprimento desta medida, o socioeducando está na maior parte do tempo efetivamente privado do seu direito de ir e vir. Em aspecto formal a semiliberdade

\footnotetext{
${ }^{5}$ de acordo com o artigo 103 do ECA, considera-se ato infracional a conduta prevista em lei como crime ou contravenção penal.
} 
corresponde, no campo das medidas sócio-educativas, ao regime semi-aberto do Direito Penal de adultos. Segundo o professor Alessandro Baratta (2000), a única diferença da semiliberdade com relação à privação de liberdade com possibilidade de atividade externa é que, nesta última, o juiz pode suspender quando julgar conveniente a atividade extra-muros. Já no caso da semiliberdade, a atividade extra-muros é parte da essência da ação educativa imposta ao educando, não podendo de forma alguma ser revogada no marco do regime em questão.

No decorrer da semana, os adolescentes habitam uma casa junto com outros adolescentes que cometeram atos infracionais, podendo ser liberados nos fins de semana para o convívio familiar, a depender da avaliação de comportamento efetuada pelos responsáveis pela execução da medida. Na casa de semiliberdade do Gama Leste, universo de pesquisa deste trabalho, a avaliação comportamental é realizada, há doze meses, por uma Comissão Avaliadora da qual participam técnicos, coordenação da entidade, dois educadores de plantão, dois adolescentes e o adolescente a ser avaliado.

Os possíveis desdobramentos da condição do adolescente atendido no regime de semiliberdade devem ser colocados de forma clara, para que o adolescente esteja ciente de sua situação frente ao cumprimento da medida. Esses desdobramentos são os seguintes:

- ele poderá ter a medida considerada cumprida e ser posto em liberdade em razão de uma resposta adequada à proposta pedagógica que lhe é apresentada,;

- ele poderá ser colocado em liberdade assistida, numa situação de progressão de regime, em razão de uma resposta com progressos parciais (incompletos);

- Ele poderá, ainda, ser privado de liberdade em razão de reiterado e injustificado descumprimento da medida anteriormente imposta em razão de uma inadaptação (resposta inadequada) a esse regime.

Embora esta medida tenha um caráter sancionatário, de responsabilização do adolescente, sua operacionalização deve ser baseada numa ação educativa, embasada na concepção de que o adolescente é sujeito de direitos e pessoa em situação peculiar de desenvolvimento, que necessita de referência, apoio e segurança. 
Para o cumprimento da medida de semiliberdade, o Estatuto considera essenciais: A) matrícula; B) As supervisões da freqüência escolar do adolescente; C) a promoção de sua profissionalização e D) tentativa de inserção do menor no mercado de trabalho. Tais ações poderão ser bem sucedidas se o trabalho for desenvolvido em três esferas: individual, familiar e comunitário. Os planos de intervenções, que devem ser elaborados pelos técnicos em conjunto com o adolescente e sua família, têm que contemplar abordagens sócio-terapêuticas, sócio-econômicas e sócioeducativas adequadas a cada situação, visando o fortalecimento e restabelecimento dos vínculos familiares e comunitários.

A concepção do atendimento em rede conta com a complementaridade e processualidade do atendimento, prevendo e exercitando a articulação cotidiana de todos as instâncias envolvidas (estrutura da SEJUS, Vara da infância e da Juventude, Conselho Tutelar, Conselho de Defesa da Criança e do Adolescente, outros órgão públicos responsáveis pela execução das demais políticas públicas).

Essa articulação deve permear toda e qualquer intervenção, pois o adolescente autor de atos infracionais é um cidadão e deve ter suas necessidades atendidas por todas as esferas do poder, principalmente por esta em situação de vulnerabilidade pessoal e social.

Se a sociedade não atender as necessidades desses adolescentes, ela será a própria vítima das eventuais violações desse adolescente, pois se sabe que os adolescentes não nascem infratores, mas é o contexto de vida em que estão inseridos que impulsionam esses jovens à prática do ato infracional.

Assim, faz-se necessário que a Medida socioeducativa de semiliberdade, intensifique a articulação com as demais políticas públicas para assegurar a inter-setorialidade na execução das medidas sócio-educativas, e estreitar a articulação com a Vara da Infância e da Juventude, com a Promotoria da Infância e da Juventude, com a Defensoria Pública, com outros órgãos de defesa de direitos e com a rede prestadora de serviços, que pode ser acionada para atender as necessidades e demandas dos adolescentes e suas famílias.

A Semiliberdade possui seis serviços:

\section{Atendimento Assistencial}


- Recepção e acolhimento do adolescente e família para a vinculação ao atendimento na Medida Socioeducativa de Semiliberdade;

- Elaboração do diagnóstico por meio da intervenção técnica;

- Elaboração do Plano de Intervenção do Atendimento - PIA;

- Captação da rede social para encaminhamento de alternativas viáveis para a superação das necessidades socioassistenciais apresentadas;

- Garantir ações socioeducativas em nível individual e grupal, encaminhando a família para programas de inserção produtiva e os demais serviços da Proteção Social Básica PSB;

- Consolidar parcerias com a rede social governamental e não-governamental responsável pela execução de programas de assistência social visando à inclusão das famílias dos adolescentes em programa de transferência de renda e benefícios assegurados por lei;

\section{Acompanhamento em atividades Socioeducativas}

- Articulação com organizações governamentais e não-governamentais da região administrativa, que desenvolvam atividades socioeducativas, tendo em vista o acompanhamento e encaminhamento dos adolescentes e familiares.

- Assessoria técnica a essas organizações, para adequação de seus serviços às particularidades dos usuários desta ação.

- Promoção de atividades visando à sensibilização e à mobilização da comunidade para o trabalho socioeducativo.

\section{Acompanhamento Escolar}

- Mapeamento e diagnóstico da situação escolar dos adolescentes.

- Articulação sistemática com as escolas visando o acompanhamento do engajamento, permanência e desempenho escolar dos adolescentes.

- Articulação com demais projetos e serviços de outros programas, para superação de dificuldades que contribuem para a infreqüência ou o mau desempenho escolar dos adolescentes.

- Promoção de atividades que visem a sensibilização das famílias para a importância da educação e sua mobilização para a participação efetiva na vida escolar dos mesmos. 
- Promoção de campanhas para juntamente com as escolas, discutir com a comunidade sobre o tema delinqüência juvenil, prestar informações sobre as Medidas Socioeducativas e engajar grupos e organizações comunitárias na recuperação dos jovens em conflito com a lei.

\section{Servico de Acompanhamento Sócio- terapêutico}

- Promoção de ações direcionadas ao acompanhamento sócio-terapêutico no cotidiano do atendimento aos adolescentes e famílias.

- Intervenção grupal na perspectiva de fortalecer a auto-estima, as relações interpessoais, pertencimento, definição de papéis, entre outros.

- Identificação de casos que demandam atendimento terapêutico especializado.

- Levantamento das principais problemáticas identificadas e das necessidades de criação e ampliação de serviços especializados.

- Encaminhamento para a rede de saúde visando aprofundamento de diagnóstico psiquiátrico e psicológico e indicação de tratamento adequado.

- Articulação com serviços de saúde para atendimentos especializados.

- Acompanhamento dos tratamentos através de contatos sistemáticos com as equipes que realizam os atendimentos.

\section{Acompanhamento Médico - odontológico}

- Utilização da rede de saúde para viabilizar o pronto-atendimento dos adolescentes.

- Promoção de ações de caráter preventivo, visando orientar os adolescentes e famílias sobre cuidados básicos com a saúde.

\section{Acompanhamento Processual}

- Elaboração de relatório técnico de acompanhamento social (avaliativo e conclusivo);

- Prestação de informações e orientações aos adolescentes e famílias sobre as exigências e os procedimentos judiciais inerentes ao cumprimento da Medida.

- Acompanhamento da execução da Medida em seus aspectos processuais (trâmite jurídico). 
- Atenção à garantia dos direitos dos adolescentes, previstos nos artigos 141 a 144 do Estatuto da Criança e do Adolescente - ECA.

- Promoção de articulação com todas as instâncias do Poder Judiciário afeta à questão do adolescente infrator.

- Promoção de articulação com organizações de defesa de direitos, visando a garantia de direitos;

- Acompanhamentos em audiência em DP's VIJ ou PD/J.

Por tratar-se de adolescentes, ou seja, menores de 18 anos, deve respeitar-se sua garantia de inimputabilidade penal ${ }^{6}$, o que não significa impunidade. A inimputabilidade diz respeito à exclusão da responsabilidade penal, que não isenta o menor da responsabilidade pessoal ou social (VOLPI, 1998). Isso significa que não se pode atribuir responsabilidade ao menor diante da legislação penal comum, mas sim, diante das normas que lhe são próprias, ou seja, as do Estatuto da Criança e do Adolescente. As medidas socioeducativas se diferem da pena criminal comum quanto ao caráter pedagógico da execução da medida e quanto a sua duração, pois a medida deve ser breve e considerar que se trata de pessoas em desenvolvimento.

\footnotetext{
${ }^{6}$ Artigo 228 da CF: "São penalmente inimputáveis os menores de dezoito anos, sujeitos às normas da legislação especial".

Artigo 104 do ECA: "São penalmente inimputáveis os menores de dezoito anos, sujeitos às medidas previstas nesta Lei".
} 


\section{CAPÍTULO 5}

\section{A EXECUÇÃO DA MEDIDA NA CASA DE SEMILIBERDADE DO GAMA - DF}

De acordo com o ECA, capítulo III, o adolescente autor de atos infracionais deve receber atendimento com o intuito de promover a capacidade de se auto-relacionar com outros pares, para superar sua condição de vulneralibilidade, visando a não reincidência na prática de delitos. Conforme o SINASE - Sistema Nacional de Atendimento Socioeducativo:

"Os parâmetros norteadores da ação e gestão pedagógicas para as entidades e/ou programas de atendimento que executam a internação provisória e as medidas socioeducativas devem propiciar ao adolescente o acesso a direitos e às oportunidades de superação de sua situação de exclusão, de ressignificação de valores, bem como o acesso à formação de valores para a participação na vida social, vez que as medidas socioeducativas possuem uma dimensão jurídico-sancionatória e uma dimensão substancial ético-pedagógica". (SINASE p. 51)

O SINASE estabelece as seguintes diretrizes pedagógicas para as entidades ou programa de execução das Medidas Socioeducativas: sancionatórios

1. Prevalência da ação socioeducativa sobre os aspectos meramente

As medidas socioeducativas (Referindo-se também a internação provisória) possuem em sua concepção básica uma natureza sancionatória, vez que responsabilizam judicialmente os adolescentes, estabelecendo restrições legais e, sobretudo, uma natureza sócio pedagógica, haja vista que sua execução está condicionada a garantia de direitos e ao desenvolvimento de ações educativas que visem à formação da cidadania. Dessa forma, a sua operacionalização inscreve-se na perspectiva ético-pedagógica.

2. Projeto pedagógico como ordenador de ação e gestão do atendimento socioeducativo

Os programas devem ter, obrigatoriamente, projeto pedagógico claro e escrito em consonância com os princípios do SINASE.[...]

3. Participação dos adolescentes na construção, no monitoramento e na avaliação das ações socioeducativas

É fundamental que o adolescente ultrapasse a esfera espontânea de apreensão da realidade para chegar à esfera crítica da realidade, assumindo conscientemente seu papel de sujeito. Contudo, esse processo de conscientização acontece no ato de ação-reflexão.[...]

4. Respeito à singularidade do adolescente, presença educativa e exemplaridade como condições necessárias na ação socioeducativa. 
[...]A ação socioeducativa deve respeitar as fases de desenvolvimento integral do adolescente levando em consideração suas potencialidades, sua subjetividade, suas capacidades e suas limitações garantindo a particularização no seu acompanhamento. Portanto, o plano individual de atendimento (PIA) é um instrumento pedagógico fundamental para garantir a eqüidade no processo socioeducativo.

5. Exigência e compreensão, enquanto elementos primordiais de reconhecimento e respeito ao adolescente durante o atendimento socioeducativo

Exigir dos adolescentes é potencializar suas capacidades e habilidades, é reconhecê-los como sujeitos com potencial para superar suas limitações. No entanto, a compreensão deve sempre anteceder a exigência. É preciso conhecer cada adolescente e compreender seu potencial e seu estágio de crescimento pessoal e social. Além disso, deve-se fazer exigências possíveis de serem realizadas pelos adolescentes, respeitando sua condição peculiar e seus direitos.

\section{Diretividade no processo socioeducativo}

A diretividade pressupõe a autoridade competente, diferentemente do autoritarismo que estabelece arbitrariamente um único ponto de vista. Técnicos e educadores são os responsáveis pelo direcionamento das ações, garantindo a participação dos adolescentes e estimulando o diálogo permanente.

7. Disciplina como meio para a realização da ação socioeducativa

[...]A questão disciplinar requer acordos definidos na relação entre todos no ambiente socioeducativo (normas, regras claras e definidas). Deve ser meio para a viabilização de um projeto coletivo e individual, percebida como condição para que objetivos compartilhados sejam alcançados e, sempre que possível, participar na construção das normas disciplinares.

8. Dinâmica institucional garantindo a horizontalidade na socialização das informações e dos saberes em equipe multiprofissional

Muito embora as ações desenvolvidas pela equipe multiprofissional (técnicos e educadores) sejam diferenciadas, essa diferenciação não deve gerar uma hierarquia de saberes, impedindo a construção conjunta do processo socioeducativo de forma respeitosa, democrática e participativa.[...]

9. Organização espacial e funcional das Unidades de atendimento socioeducativo que garantam possibilidades de desenvolvimento pessoal e social para $o$ adolescente

O espaço físico e sua organização espacial e funcional, as edificações, os materiais e os equipamentos utilizados nas Unidades de atendimento socioeducativo devem estar subordinados ao projeto pedagógico, pois este interfere na forma e no modo de as pessoas circularem no ambiente, no processo de convivência e na forma de as pessoas interagirem, refletindo, sobretudo, a concepção pedagógica, tendo em vista que a não observância poderá inviabilizar a proposta pedagógica.

norteadora da prática pedagógica

10. Diversidade étnico-racial, de gênero e de orientação sexual

Questões da diversidade cultural, da igualdade étnico-racial, de gênero, de orientação sexual deverão compor os fundamentos teórico-metodológicos do projeto pedagógico dos programas de atendimento socioeducativo; sendo necessário discutir, conceituar e desenvolver metodologias que promovam a inclusão desses temas, interligando-os às ações de promoção de saúde, educação, cultura, profissionalização e cidadania na execução das medidas socioeducativas, possibilitando práticas mais tolerantes e inclusivas. socioeducativa

11. Família e comunidade participando ativamente da experiência

[...]As práticas sociais devem oferecer condições reais, por meio de ações e atividades programáticas à participação ativa e qualitativa da família no processo socioeducativo, possibilitando o fortalecimento dos vínculos e a inclusão 
dos adolescentes no ambiente familiar e comunitário. As ações e atividades devem ser programadas a partir da realidade familiar e comunitária dos adolescentes para que em conjunto - programa de atendimento, adolescentes e familiares - possam encontrar respostas e soluções mais aproximadas de suas reais necessidades.[...]

\section{Formação continuada dos atores sociais}

A formação continuada dos atores sociais envolvidos no atendimento socioeducativo é fundamental para a evolução e aperfeiçoamento de práticas sociais ainda muito marcadas por condutas assistencialistas e repressoras. Ademais, a periódica discussão, elaboração interna e coletiva dos vários aspectos que cercam a vida dos adolescentes, bem como o estabelecimento de formas de superação dos entraves que se colocam na prática socioeducativa exigem capacitação técnica e humana permanente e contínua considerando, sobretudo o conteúdo relacionado aos direitos humanos.[...]

A casa de Semiliberdade do Gama Leste, com a finalidade de atender a essas diretrizes, tem desenvolvido diversas atividades de cunho sócio-pedagógico. Mensalmente são realizadas reuniões sócio-terapêeuticas com os adolescentes em cumprimento com a Medida e com a sua família. O projeto em questão almeja trabalhar a perspectiva de reconhecer a importância da família no desenvolvimento do adolescente objetivando trabalhar a relação do adolescente com a sua família e fortalecendo esses vínculos, com vistas à emancipação dos sujeitos pela sensibilização e conscientização, no que se refere aos direitos e deveres, das várias famílias que possuem filhos em cumprimento de Medida de SemiLiberdade na Casa do Gama Leste.

Entre as atividades propostas, ocorre um vez por semana, o cine club, que consiste na projeção de um filme, onde, posteriormente discute-se o seu conteúdo, abordando questões como: família, drogadição, sexo, violência, dentre outros. E temos ainda, a fim de promover a prática desportiva e o lazer, um projeto no qual duas vezes por semana os adolescentes são levados à realizar atividades esportivas.

Em relação a profissionalização, três vezes por semana os adolescentes participam de cursos na escola de inclusão digital, durante uma hora por dia realizam curso de operador de microcomputadores nas obras sociais pavonianas e têm aulas de manuntenção e configuração de microcomputdores no centro de recondicionamento de computadores três vezes por semana.

Esporadicamente, são realizadas atividades de lazer tais como: visitação aos pontos turísticos Brasília, idas ao cinema e clube. Cabe ressaltar que para a realização dessas atividades de inclusão, de cursos e programas sócio-assistenciais, é utilizada a própria rede 
social da comunidade. É importante destacar que os parcos recursos dificultam a realização dessas atividades.

Para o funcionamento da Casa conta-se com uma equipe de 28 funcionários, composta por duas técnicas, Psicóloga e Assistente Social, uma coordenadora graduada em serviço Social e 25 educadores concursados em nível médio.

A casa tem capacidade para comportar doze adolescentes. Atualmente, há dez adolescentes cumprindo a medida. No entanto, esse numero é bastante volátil devido às constante evasões e à chegada de novos adolescentes.

Para uma maior compreensão do trabalho desenvolvido pelos socioeducadores nas unidades de Semiliberdade, foi realizado um estudo de caso na casa de semiliberdade do Gama Leste - DF, mediante aplicação de uma pesquisa, a qual propiciou a análise qualitativa dos dados. O objetivo desse estudo de caso é obter uma maior compreensão da perspectiva em que tem sido desenvolvido o trabalho dos educadores sociais dentro das casas de semiliberdade, se é pautado na ótica da educação ou da punição.

Para aprimorar os resultados, deu-se continuidade ao levantamento da literatura sobre os temas punição; autoridade; disciplina; hegemonia e contra hegemonia; controle social; medidas socioeducativas; adolescente autor de atos infracionais e o Estatuto da Criança e do Adolescente. A pesquisa foi realizada em livros que tratam do assunto e na Internet, em consultas a sítios que fornecem dados relevantes para o objetivo da pesquisa, como: Instituto Brasileiro de Geografia e Estatística - IBGE, Scientific Electronic Library Online - SCIELO e do Núcleo de Estudo de Violência da USP - NEV.

A escolha por uma pesquisa qualitativa deu-se em razão de sua importância na analise dos fenômenos que não podem ser quantificados com riqueza e profundidade, pois como afirma Maria Minayo "A abordagem qualitativa aprofunda-se no mundo dos significados das ações e relações humanas, um lado não perceptível e não captável em equações, médias e estatísticas”. (Minayo, 2002 p. 22).

Segundo Minayo, o objeto das ciências sociais é histórico, ou seja, quem dá sentido ao trabalho não é apenas o investigador, mas toda a sociedade, quem dá significado e intencionalidade às suas ações (Minayo, 2002). Diante dessa realidade complexa, surge a necessidade de trabalhar-se com a pesquisa qualitativa, pois ela "também formaliza, mas procura preservar a realidade acima do método" (Demo, 2001 p.10) 
A pesquisa realizada teve como universo a casa de semiliberdade do Gama Leste. Esse universo de pesquisa foi escolhido devido a sua importância na execução da medida de Semiliberdade, por comportar até doze adolescentes, além de ter sido o campo de estágio curricular optado durante o $1^{\circ}$ semestre de 2007, e devido à escassa discussão teórica sobre a medida .

A amostragem foi composta por seis adolescentes, seis orientadores, uma assistente social, uma psicóloga e um coordenador da casa. com isso almejamos lograr dados qualitativos suficientes para a confirmação ou refutação da hipótese. A escolha dessa amostragem considerou os dados quantitativos e a necessidade de explorar, de forma qualitativa, as entrevistas realizadas.

Com relação à aplicação da pesquisa, foi realizada entrevista semi-estruturada nos dias 9, 10, 13 e 16 de julho de 2008, com onze perguntas para os socioeducadores, técnicos e coordenadores e com nove perguntas para os socioeducandos. As perguntas abordaram aspectos que envolvem a trajetória profissional dos socioeducadores e seu entendimento sobre medidas socioeducativas. Com os educandos pretendeu-se aferir se o trabalho dos socioeducadores tem sido na perspectiva educacional ou punitiva.

Para a composição da amostra foram escolhidos os adolescentes com maior tempo de cumprimento da medida de Semiliberdade, incluindo outras passagem pela mesma medida. Dentre os educadores, assistente social e coordenadores foram selecionados aqueles que possuem maior tempo de experiência na aplicação da medida de semiliberdade. O critério de tempo de vinculação ao trabalho com as medidas socioeducativas foi escolhido com a finalidade de obter-se um resultado mais apurado.

As respostas das entrevistas semi-estruturadas foram submetidas à analise de conteúdo e categorizadas a posteriori. A realização do trabalho de campo e de levantamento de dados ocorreu como se segue:

Fontes secundárias:

- Sistema nacional de atendimento socioeducativo - SINASE

- $\quad$ Estatuto da criança e do adolescente - ECA.

Fontes Primárias:

- Entrevista semi-estruturada com os socioeducadores, socioeducandos, psicólogos, assistente sociais e coordenadores da casa de semiliberdade do Gama Leste 


\section{CAPÍTULO 6}

\section{ANÁLISE DOS DADOS}

\subsection{Trajetória profissional dos socioeducadores nas medidas socioeducativas}

A análise dos dados das quinze entrevistas realizadas na casa de semiliberdade do Gama Leste, apontou que os socioeducadores possuem idade entre 44 e 54 anos, dois com o ensino fundamental, três com ensino médio e um graduado em pedagogia. Todos eles possuem longa trajetória profissional na execução das Medidas Socioeducativas: Em média, têm vinte e três anos de trabalho com adolescentes autores de atos infracionais, dos quais, entre dez e quinze anos, foram dedicados à medida de semiliberdade.

Todos os entrevistados relataram que não tinham planos de trabalhar com adolescentes em conflito com a lei, mas que, por falta de opções passaram a dedicar-se a esse trabalho e resolveram nele permanecer. a resposta a seguir reflete bem essa situação:

ED "Quando fui para as medidas eu não fui por opção fui por transposição do serviço. Fui colocada pra trabalhar lá. O que me motivou a exercer essa profissão? Não sei... não tive motivação foi por acaso, não tinha muita escolha, então acabei ficando por aqui até hoje".

A satisfação por estar desempenhando a função de socioeducador manifestou-se na resposta de dois entrevistados, enquanto que os demais relatam apenas já estarem acostumados ao trabalho:

EC "Quando fiz o concurso eu fui trabalhar na creche domiciliar que era um projeto que tinha na fundação do serviço social, $\log$ depois eu fui para LA e gostei. Fiquei na LA por muito tempo, depois fui chamada a atuar na semi e estou aqui ate hoje, mas eu vejo que eu tenho muito amor no que eu faço. Eu faço por amor".

EF "Sempre trabalhei com adolescente, desde o começo, então... Na verdade eu já me acostumei com esse trabalho".

Todos os socioeducadores entrevistados trabalharam na execução da Política Nacional de Bem-Estar do Menor - PNBEM e tiveram a oportunidade de conviver o dia-a-dia 
da aplicação do Código de Menores, vigente no período. Dessa forma, esses funcionários receberam uma formação profissional perpassada por uma lógica correcional, repressiva e assistencialista, marcantes no período anterior ao Estatuto da Criança e do Adolescente. Diante disso, procurou-se verificar se a implantação do Estatuto da Criança e do Adolescente conseguiu romper com as antigas práticas institucionais entre os socioeducadores que atuam na casa de semiliberdade do Gama Leste pela observância, ou não, das disposições do ECA, passando a ser efetivada uma prática em concordância ao que esta disposta no Estatuto da Criança e do Adolescente (ECA).

\subsection{Quem é o adolescente que chega na semiliberdade?}

A concepção dos socioeducadores sobre o adolescente que chega na semiliberdade esta dividida em dois grupos: aqueles que acreditam que se trata de um adolescente vítima do descaso do Estado, da sociedade e da falta de uma estrutura familiar que fosse capaz de educalo e aqueles que acreditam que o adolescente está na medida porque deve à justiça e à sociedade e que, portanto, deve pagar pelos seus delitos. Esse grupo não percebe as questões sociais que envolvem o ato infracional cometido por adolescentes, porque possui apenas uma visão positivista sobre o assunto. Isso é evidenciado nas seguintes respostas:

EC é um infrator que faz bobagem na rua que não obedece às leis

EF é um adolescente sentenciado por algum ato infracional. É alguém que deve a justiça.

EE "É um garoto que ta solto ele não tem a quem se apegar, está totalmente perdido, ele é uma doença social, não é uma doença patológica. Ele é um doente a sociedade adoeceu ele".

Esse grupo transfere a responsabilidade da prática do ato infracional apenas ao próprio adolescente, pois o percebe como indivíduo que possui maturidade e discernimento sobre suas atitudes e, portanto capaz de responder pelos seus atos. Essa forma de ver o adolescente leva o grupo de educadores a pensar que os educandos são merecedores de um sistema mais rígido e punitivo. Esse pensamento ficou explícito na seguinte resposta: 
ES "Eu acho que o estatuto tem que ser reformulado tanto quanto ao tempo de internação que deveria ser maior, quanto a outras medidas o governo o poder público o deveria tomar medidas mais enérgicas que chamasse as famílias à responsabilidade que chamasse todas as políticas publicas a responsabilidades. Então o estatuto fica aquém do que ele deveria. $\mathrm{O}$ adolescente não pode votar aos 16 anos? Não pode escolher o presidente que vai governar o país? Então ele pode arcar judicialmente seus atos".

Essa fala demonstra o pensamento de culpabilização do adolescente e de sua família sobre o ato infracional. Apesar do Estatuto da Criança e do Adolescente estabelecer que crianças e adolescente são responsabilidade da família, da sociedade e do Estado, ainda há orientadores que não têm esse entendimento, transferindo a responsabilização para o próprio adolescente. Os socioeducadores reconhecem que se trata de um pensamento comum entre os educadores de culpar os adolescentes autores de atos infracionais pelos seus atos, ao contrário do que estabelece o artigo $6^{\circ}$ do ECA, que trata esses infratores como pessoas em desenvolvimento.

EC "Eu acho que o que deveria esta mudando e os servidores esta vendo esse menino como seres humanos que eles são adolescentes. Os educadores têm que entender que são meninos, muitos ate dizem você fala menino eles são uns marmanjos, bandidos que sabem muito bem o que estão fazendo".

EC "Tem colegas de trabalho que defende a redução da maioridade penal, que acha que isso tem que ocorrer, dizem que eles são bandidos que eles já tem consciência, já sabem o que fazem e que eles já podem responder pelos seus atos. Eu penso que os adolescentes podem até ter consciência de seus atos, mas acho que eles estão em fase de desenvolvimento".

Todavia, cabe ressaltar que não são todos os educadores que tem essa concepção a respeito dos adolescentes. Dos seis entrevistados, dois reconheceram esses adolescentes como sendo vítimas de uma falha da participação dos três atores sociais, família, sociedade e Estado, no processo de sua formação.

\subsection{Medida socioeducativa versus punição}

A presente pesquisa revela que os socioeducadores vêem o Estatuto da Criança e do Adolescente como um avanço, uma inovação, um instrumento de uso como defesa dos adolescentes, mas que não se aplica na prática. Os educadores apontam falhas no Estatuto e mudanças que deveriam ser levadas a cabo, tais como a redução da maioridade penal e o aumento do tempo de internação. 
A maioria dos educadores revelou um desejo de que o Estatuto tenha medidas mais rígidas em relação ao adolescente autor de atos infracionais, sugerindo como melhor medida a redução da maioridade penal, porque a medida socioeducativa não seria suficiente para o adolescente "pagar sua dívida" com a sociedade. A medida socioeducativa é vista como uma forma de deixar impune o crime cometido por um adolescente.

ED "O Estatuto tinha que reduzir a maioridade penal botar pra 16 anos. Eu acredito que vai melhorar muito a aprontação desses meninos".

ES "tem que ter redução da maioridade penal, o adolescente tem que ter na consciência dele, e é isso que tentamos desenvolver aqui dentro, que se ele fez algo errado ele tem que pagar por isso é que estamos aqui pra tentar ajuda-lo a não errar mais, então acho que a semiliberdade tem que ter mais rigidez".

ES "talvez não surta efeito de imediato, mas você pode ter certeza que depois de algum tempo que a redução da maioridade penal estiver implantado a criminalidade vai diminuir, isso é o que eu penso. A certeza da impunidade faz com que ele cometa o crime uma, duas, três vezes entendeu? Ele acha que a proteção que ele tem hoje ele vai ter daqui uns 20 anos e não é assim”.

Diante disso, temos um quadro onde aqueles que executam a medida socioeducativa não a vêem como meio eficaz de ressocialização. Os orientadores afirmam que a medida socioeducativa é uma forma de ressocializar os adolescentes, mas alguns acrescentam que, na prática, o caráter punitivo deveria estar presente. A promoção da cultura, lazer, educação e todos os pontos que compõe uma medida socioeducativa é compreendida pelos educadores como uma medida de proteção que incentiva a prática criminal. Segundo esses educadores, os educandos somente mudarão de comportamento se tiverem consciência de que pagaram pelos seus ato. Ou seja, a mudança viria por meio da lógica da punição. Essa forma de pensar condiz com o que Foucault relatava: “a certeza de ser punido é que deve desviar o homem do crime" (Foucault, 1987 p.13).

Segundo a resposta de dois educadores, da equipe técnica e da coordenação, esse tipo de pensamento construído por alguns educadores sobre a lógica punitiva como forma ideal de ressocialização, são resquícios da formação recebida quando eram funcionários da Funabem, evidenciando a continuidade de uma cultura punitiva:

EE "A maioria dos servidores tem uns 20 anos de trabalho é preciso fazer essa reciclagem, saber acompanhar as mudanças, tem colegas que tem a mesma mentalidade de 20 anos atrás, uma mentalidade autoritária, então deveria ter uma 
reciclagem, novos cursos novos treinamentos. Então eu acho que esse modelo de educador que esta aí esta truncando a política de atendimento desses adolescentes".

TG "Querendo ou não do estatuto pra cá é muito pouco tempo, são 18 anos, mas isso representa pouco tempo pra mudar essas pessoas que trabalharam na funabem, cose... se bem que o cose era melhor, pois trabalharam com criança, por isso em geral esses são melhores educadores do que aqueles que trabalharam com internação de meninos infratores. Esses que trabalharam na funabem em geral seguem uma linha mais autoritária, mais ditatorial. Falta informar pra todo mundo o que é a medida socioeducativa, pois muitos educadores ainda não entende o que é isso, não entende o que o ECA estabelece".

Percebe-se que há uma cultura hegemônica dentro da casa de semiliberdade, onde a formação recebida durante o trabalho na Funabem ainda não foi superada com a implantação do ECA. A lógica do controle mantido pela disciplina, regras, punição e autoritarismo foram mantidas, o que reflete na postura profissional.

EC “Temos alguns colegas que vieram da antiga Funabem do tempo em que não tinha nem o Estatuto, era um período de formação meio militaresca, policial, de um regime ditatorial onde impera a força, e esses educadores continuam agindo assim".

Isso demonstra que há uma luta em defesa da criança e do adolescente, para que o Estatuto da Criança e do Adolescente seja implementado na sua integridade e que se desconstrua a hegemonia dominante que existe sobre a forma de exercer o controle sobre adolescentes que cometem ato infracional. Porém, existe uma força contrária que resiste à implementação de novas idéias, formando uma correlação de forças.

EE “a gente fala: vamos fazer um curso? Mas eles não querem, eles não se aprimoram nas novas idéias eles ficam sempre batendo na mesma tecla, eles são muitos fechados para as idéias, continuam pensando como há vinte anos atrás”.

As regras e a disciplina estão previsto no SINASE e fazem parte do processo educativo, assim como a imposição de limites desde que haja respeito à individualidade e às peculiaridades de cada adolescente. O SINASE prevê o trabalho socioeducativo atrelado à compreensão como elementos primordiais de reconhecimento e respeito ao adolescente, enquanto a disciplina é um meio para a realização da ação socioeducativa. Diante disso, fica clara a necessidade do estabelecimento de regras, limites e disciplina como elementos do processo socioeducativo. Porém, é importante perceber que a medida socioeducativa não se 
limita a esses três elementos, vez que existem elementos importantes a serem considerados, tais como compreensão, afeto e o diálogo.

O tripé disciplina, regras e limites foi apontado por quatro dos socioeducadores como sendo o único elemento que falta para os socioeducandos. Outros dois apontaram que, apesar de não verem dessa forma, na realidade o tripé é o que prevalece na casa de semiliberdade do Gama Leste. Essa percepção também ficou evidente nas respostas das técnicas e da coordenação:

CE "Eles falam que o que tem que ter é somente regras disciplinas e limites eles vêem a semiliberdade como uma extensão do caje. Não existe a questão do processo socioeducativo, eles vêm que o menino é obrigado a estudar é obrigado a ir pro curso, eles não vêm isso como forma de evolução desse adolescente. $\mathrm{O}$ adolescente tem que entender que isso é bom pra ele, que ele tem que fazer isso para o bem dele. Então eles querem apenas obrigar, fazer tudo a força".

EF "disciplina, regras e limite são as palavras pelas quais tenho trabalhado há 20 anos".

ES "na casa de semiliberdade tem que ter regras disciplina e limites e esclarecer o que vai acontecer com eles se eles não obedecerem".

A presente pesquisa revela que disciplina, regras e limites têm sido usado como meio de punir e não de educar, conforme estabelecido pelo SINASE. Isso ficou evidente tanto nas respostas dos orientadores quanto nas dos técnicos e socioeducandos.

Os entrevistados apontam que a maioria dos educadores percebe que, para manter o controle e a ordem dentro da casa e fazer com que o adolescente mude de comportamento, fazse necessário o uso da punição. Para isso, usam-se do tripé disciplina, regras e o limite para punir:

EE “a educação tem que prevalecer sobre as regras. Aqui às vezes estamos jogando um dominó com o menino, a hora de recolher pra durmir é às 23 horas, às vezes naquele jogo alí eu to tendo uma conversa com o menino, ele está desabafando está partilhando alguma coisa que aconteceu aí vem a hora de dormi hora de recolher, vem meus colegas monitores e tiram o dominó. O processo educativo tem que ser acima disso aí. Se eu estou tendo uma conversa que é proveitosa, que hoje ou amanha pode trazer algum fruto, tem que prevalecer sobre o horário dele entrar. Eles vêm e retiram o dominó, mas será que eu vou ter a oportunidade de novo de continuar aquilo? Será que aquele adolescente vai me dar abertura novamente? Aquela foi uma forma de acessar o adolescente é a minha chance de está trabalhando essa mudança. Então as regras não podem sobressair sobre o processo educativo". 
$\mathrm{Na}$ fala acima ficou claro como os educadores, no seu agir profissional, priorizam as regras, disciplina e os limites, pondo em segundo plano o processo de educação. Os adolescentes apontam essa prática profissional como similar ao trabalho policial. Os socioeducandos, alguns técnicos e coordenador percebem que o trabalho dos educadores ainda é o de monitor e não de socioeducador, como evidenciado na resposta a seguir:

CE "Na verdade eles acham melhor trabalhar na força, na contenção, do que trabalhar com o diálogo, então eles preferem trabalhar com a contenção e não com o diálogo, eles preferem trabalhar não como educadores, mas preferem trabalhar como monitores e é assim que os meninos os chamam, de monitores. Eles não tem nada de socioeducadores, eles só sabem vigiar, o SINASE diz agora que temos que chamalos de socioeducadores e os adolescentes são socioeducandos, mas na verdade em 20 anos não tivemos nem agentes sociais. Os meninos não os chamam de educadores eles ainda os chamam de monitores ai você já pode perceber que nada aconteceu. A minha visão e de meus colegas é que infelizmente eles não são educadores são monitores".

AF "as únicas que podem me ajudar é a coordenadora e a assistente social, o resto não, eles só olham a gente não ajudam em nada”.

O caráter policial torna-se evidente na prática profissional dos educadores, que passam a ser percebido pelos adolescentes, equipe técnica e coordenação como personagens que exercem a função de punir e monitorar. Esse caráter policial também é reconhecido por alguns socioeducadores que afirmam assumir essa faceta, mesmo estando na função de monitorar, resultando numa conduta profissional repressora e autoritária. Essa questão foi bem exposta nas observações dos adolescentes a seguir:

AL "A semiliberdade é uma casa que tem mais polícia que bandido, por causa desses monitores, tudo que eles quer é só ser policia, até intimar nos eles já intimou, intimou pra porrada pra trocar tiro na rua".

AR "Eu acho que os adolescentes deveria ir pra escola assim mais desacompanhado já que aqui e uma casa onde agente tem que viver com a comunidade os adolescente tinha que andar só, não digo nada aqueles que apronta no meio da rua mesmo estando na casa, mas aquele que são de boa tinha que ir pra escola tranqüilo sem monitor".

AR "Muitos orientadores são de boa, mas têm outros que eu mesmo não vou com a cara deles, por que eles não sabem fazer o serviço direito. Tem muitos que é uma coisa, mas quer ser polícia, quer agir como polícia, a gente ta aqui pra ser educado, mas eles querem agir como polícia, como se agente estivesse preso no presídio mesmo, igual muitas vezes eles já falaram que a gente ta é preso, aí toda vez que eles falam isso eu falo que aqui não é presídio". 
A punição é vista como forma de assegurar que a disciplina será cumprida, pois as regras devem ser vistas como sagradas e invioláveis. A falta de punição adequada às transgressões leva ao questionamento e fragilização das regras. Pensamento bem retratado por Foucault, que trabalha a questão da punição como veículo de disciplina, ou seja, a punição é um meio para a normalização é uma forma de assegurar que a disciplina reina sobre a sociedade.

Com a mudança de paradigma trazido pelo Estatuto da Criança e do Adolescente de uma visão "minorista" para a doutrina de proteção integral, novas políticas de atendimento a adolescentes em conflito com a lei foram formuladas. A exemplo disso temos o SINASE, que oferece as diretrizes do atendimento socioeducativo. Contudo, a formulação e divulgação dessas mudanças não foram suficientes para a ruptura com o passado. As práticas profissionais dos socioeducadores da casa de semiliberdade do gama leste apresentaram-se como uma prática atrelada a cultura punitiva. Isso tem demonstrado que ainda há uma cultura hegemônica de que a punição é a medida eficaz para quem transgride as leis, tanto para adultos como para adolescentes. 


\section{CONSIDERAÇÕES FINAIS}

A construção deste trabalho teve o objetivo de avaliar se a execução do trabalho dos socioeducadores na casa de semiliberdade do Gama Leste ultrapassou a lógica da punição e passou a adotar, de fato, um trabalho socioeducativo.

Com o resgate histórico estabelecido ao longo do trabalho, ficou claro que o enfrentamento da questão dos adolescentes autores de atos infracionais foi perpassado por uma lógica punitiva. Nem mesmo com a mudança de paradigma trazido pelo Estatuto da Criança e do Adolescente, de proteção integral dos menores de idade, foi capaz de mudar velhas práticas profissionais. A herança do sistema anterior continua arraigada na atuação profissional dos socioeducadores, conforme foi demonstrado na análise dos dados coletados.

As mudanças no campo legal não foram acompanhadas por mudanças práticas. Apesar da existência de socioeducadores que procuram desenvolver um trabalho socioeducativo, a cultura punitiva ainda é a prática dominante, porque a punição é vista como meio eficiente de manter a disciplina e o respeito às regras impostas.

Este trabalho denota que faz-se necessário um esforço para sensibilizar os socioeducadores no intuito de implementar um trabalho socioeducativo, embasado pelo ECA e pelo SINASE, para levar a cabo o rompimento com o passado, concretizando assim, os direitos das crianças e do adolescente.

Diante disso, torna-se evidente a necessidade de estarem sendo desenvolvidas capacitações profissionais de forma sistemática e continua para todos os funcionários. Por meio dessa ação poderia facilitar o processo de desconstrução da cultura punitiva já introjetada no imaginário dos socioeducadores. 


\section{REFERÊNCIAS BIBLIOGRÁFICAS}

Amnesty International BULLETIN D'INFORMATION 100/03 jeudi 24 avril 2003. Brésil: le febem de São Paulo : le pays est-il condamné à un avenir marqué par la violence ?. acessado em 21/11/2007 em: http://www.amnesty.org/es/library/asset/AMR19/009/2003/fr/dom-AMR190092003fr.pdf

ARIES, Philippe. Historia social da criança e da família. 2. ed. Rio de janeiro: Ed Guanabara, 1986. 279 p.

BARATTA, A. Do regime de Semiliberdade In: Estatuto da criança e do adolescente comentado: comentários jurídicos e sociais. 3. ed. São Paulo: Malheiros, 2000.

Brasil. Constituição Federal do Brasil. Rio de Janeiro: Esplanada 2002.

CARVALHO, Denise B. B. de. Políticas sociais e Direitos Humanos: trajetórias de violação dos direitos de cidadania de criança e adolescentes. In: Direitos Humanos e Políticas Sociais. Ser Social: revista do Programa de Pós-graduação em Política social/ Universidade de Brasília. Departamento de Serviço Social - v.1, n.1 (1º semestre,1995). Brasília, SER/UNB, 1995.

CMDCA - Campinas-SP (2005). Estatuto da Criança e do Adolescente. 15ª Ed., São Paulo:CMDCA

DEMO, Pedro. Pesquisa e informação qualitativa. Campinas: Papirus, 2001.

FULCAULT, Michael. Vigiar e Punir: História da violência nas Prisões. 31 ${ }^{\mathrm{a}}$ ed. Petrópolis: Vozes, 2006. 262 p.

FUCKS, Andréa Márcia s. 1. Entre o Direito Legal e o Direito Real: O Desafio à Efetivação da Cidadania do Adolescente Autor de Ato Infracional (A Experiência da Medida Sócio-educativa de Semiliberdade). 2004. Dissertação (Mestrado em Política Social) - Departamento de Serviço Social, Universidade de Brasília, Distrito Federal, 2004. 
GRUPPI, Luciano. O Conceito de hegemonia em Gramsci. 3.ed. Rio de Janeiro: Graal, 1991.

INSTITUTO BRASILEIRO DE GEOGRAFIA E ESTATÍSTICA. Departamento de população e indicadores Sociais, IBGE 2001.

JANOSKI. Para a discussão do conceito de sociedade civil. In: Cidadania e globalização Vieira, 1997. Disponível em: http://www.dhnet.org.br/direitos/direitosglobais/cidadaniaglobal/cid_civil.html

GAlliANO, A Guilherme. A sociologia como Ciência: a construção do objeto. In: Introducao a sociologia. Porto alegre: Harbra, 1986. 336 p.

GARCÍA MÉNDEZ, Emilio; COSTA, Antônio Carlos Gomes da. Das necessidades aos direitos. Sao Paulo: Malheiros, 1994. 165 p. (Série direitos da criança;4)

Guia de orientação $\mathrm{n}^{\mathrm{o}} 1$ ( $^{\mathrm{a}}$ versão).Centro de Referencia Especializado de Assistência Social - CREAS.

MINAYO, Maria Cecília de Souza (Org). Pesquisa social: teoria, método e criatividade. Petrópolis: Vozes, 2002.

NOGUEIRA, Paulo Lúcio. Comentários ao código de menores. 3. ed. Sâo Paulo: Saraiva, 1987. $281 \mathrm{p}$

Proposta de Reordenamento dos Centros de Desenvolvimento Social- CDS/CREAS. Documento GPSE/pasta CREAS. Doc. 2006.

TEIXEIRA, Sônia Maria Fleury. Assistência na Previdência Social - uma política marginal. In: SPOSATI, A., FALCÃO, Maria do C. e TEIXEIA, S. M. F. OS direitos (dos) desassistidos sociais. SP, Cortez, 1993.

SILVA, Maria Liduina. de Oliveira e. O Estatuto da Criança e do Adolescente e o Código de Menores: descontinuidades e continuidades. In: Serviço Social e Sociedade. São Paulo Ano XXVI no 83 p. 30 - 48 Setembro de 2005. 
SISTEMA NACIONAL DE ATENDIMENTO SOCIOEDUCATIVO - SINASE. Acessado em: 15 de novembro de 2007. Em: http://www.promenino.org.br/Portals/0/Legislacao/Sinase.pdf

UNESCO. A visão dos atores: Entre Discurso e Prática. In: Políticas Públicas de/para/com Juventudes, 2004 p. 79 a 81.

VOLPI, Mario; SARAIVA, Joao Batista Costa. Adolescentes e a lei: O direito dos adolescentes, a pratica de atos infracionais e sua responsabilizacao(os). Brasilia: Ilanud, 2000. $117 \mathrm{p}$

ALBUQUERQUE, J. A. G. Althusser, a ideologia e as instituições. In: Aparelhos ideologicos de estado: Nota sobre os aparelhos ideologicos de estado. Rio de janeiro: Graal, 1983.

GDF. Histórico e dados demográficos de Ceilândia. Site Oficial do Governo do Distrito Federal. Disponível em: www.distritofedera.df.gov.br acesso em 20 de setembro de 2006. 
ANEXOS 
GUIA DE ENTREVISTA (01)

socioeducadores, técnicos e coordenadores

1. Qual sua idade?

2. Qual sua escolaridade?

3. Local de moradia

4. Faz quantos anos que você trabalha em medida socioeducativa?

5. O que te motivou a exercer essa profissão?

6. Para você quem é o adolescente que recebe a medida de Semiliberdade?

7. Qual a sua opinião sobre o Estatuto da Criança e do Adolescente?

8. O que seria para você uma medida socioeducativa?

9. Como você acha que deveria funcionar uma casa de semiliberdade?

10. Você acredita que o que falta para os adolescentes autores de atos infracionais são regras, disciplina e limites?

11. Você acha que a medida socioeducativa pode mudar o comprtamento de um adolescentes?

12. Como educador o que você sugeria para melhorar o atendimento de uma casa de semiliberdade? 


\section{GUIA DE ENTREVISTA (02) \\ Socioeducando}

1. Qual sua idade?

2. Qual sua escolaridade?

3. Local de moradia

4. Breve relato de passagem pelas medidas socioeducativa (quais já cumpriu, por quanto tempo, onde...)

5. O que você compreende por medida socioeducativa?

6. Para você o que é uma casa de semiliberdade?

7. Como você acha que deveria ser uma casa de semiliberdade?

8. Você acredita que você deve mudar?

9. Você acha que o Estado (casa de semiliberdade) pode ajudá-lo a mudar? 